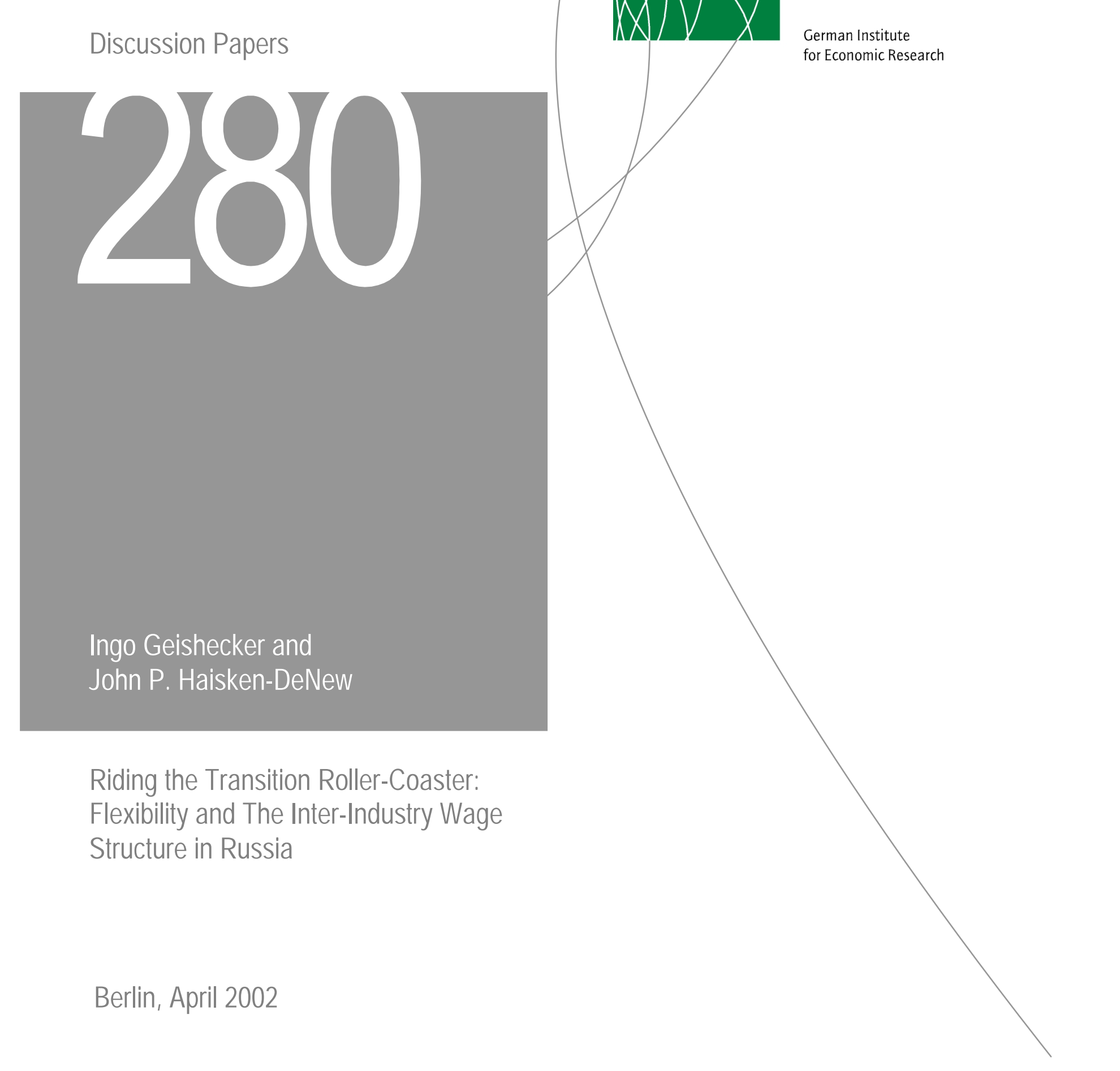


Opinions expressed in this paper are those of the author and do not necessarily reflect views of the Institute.

\section{DIW Berlin}

German Institute

for Economic Research

Königin-Luise-Str. 5

14195 Berlin,

Germany

Phone $+49-30-89789-0$

Fax +49-30-897 89-200

www.diw.de

ISSN 1619-4535 


\title{
Riding the Transition Roller-Coaster: Flexibility and The Inter-Industry Wage STRUCTURE IN Russia ${ }^{\mathrm{a}}$
}

\author{
Ingo Geishecker ${ }^{\mathrm{b}}$ and John P. Haisken-DeNew ${ }^{\mathrm{c}}$
}

26th February 2002

\begin{abstract}
This paper examines the changes in the inter-industry wage structure experienced by Russia since 1993, as part of its transition from a plan-based economy to a more "market oriented" structure. Using two Russian household panel data sets, the RLMS and the RUSSET, we find that since the transformation process began, the dispersion of inter-industry wage structure has increased. Moreover, Russia exhibits large movements in wage premia, as industries respond to massively changing demand conditions. The issue of wage arrears (unpaid wages or outstanding pay), which affects half of all employees, plays an important role in the determination of wages. Studies, which do not account for wage arrears, overestimate the overall inter-industry wage dispersion. Despite movements towards a privatized market economy, we still find government ownership and Soviet network effects play an important role in determining the wage structure.
\end{abstract}

Keywords: Inter-Industry Wage Differentials, Transition Economies, Wage Arrears, Networking

JEL classification: J24, J31, P23

$\begin{array}{ll}\text { Ingo Geishecker } & \text { John P. Haisken-DeNew } \\ \text { DIW Berlin } & \text { DIW Berlin } \\ \text { International Economics } & \text { SOEP } \\ \text { D-14191 Berlin } & \text { D-14191 Berlin } \\ \text { Germany } & \text { Germany } \\ \text { Tel: }+49-30-89789-610 & \text { Tel: }+49-30-89789-461 \\ \text { Fax: +49-30-89789-108 } & \text { Fax: +49-30-89789-109 } \\ \text { E-mail: igeishecker@diw.de } & \text { E-mail: jhaiskendenew@diw.de }\end{array}$

\footnotetext{
${ }^{a}$ We would like to thank Katherina Dittmann (DIW Berlin, WLT), Paul Gregory (U Houston), Laura Henderson (RLMS), Onno Hofmeister (DIW Berlin, SOEP), Willem Sarris (RUSSET), Mechthild Schrooten (DIW Berlin, WLT), William van der Veld (RUSSET).

${ }^{\mathrm{b}}$ DIW-Berlin.

${ }^{\mathrm{c}}$ DIW-Berlin and IZA-Bonn.
} 


\section{Introduction}

The structure of inter-industry wage differentials in the United States is well documented, for example in Krueger and Summers (1988), Murphy and Welch (1992) and Gibbons and Katz (1992). Very little research has been undertaken in the area of the inter-industry wage structure for Russia. Gregory and Kohlhase (1988) examine the wage structure using a sample of Russian immigrants to the United States. However, two household panel data sets have recently become available for Russian residents: the Russian Longitudinal Monitoring Survey (RLMS) and the Russian Socio-Economic Transition Panel (RUSSET). The aim of this paper is to examine the structure of and changes in the inter-industry wage structure in Russia during the period 1993-1999. We follow and expand on the example of Haisken-DeNew and Schmidt (1997) in calculating industry wage differentials and we expand on this. In Section II, background information is provided on the Soviet and Post-Soviet wage structure and wage setting mechanisms. We discuss the common phenomenon of "wage arrears", experienced by about half of all employees over this time period. In Section III, we outline the two Russian household panel data sets used in the analysis. In Section IV, we provide estimates of the Russian wage structure, concentrating on inter-industry wages, also discussing the effects of government ownership, unobserved individual heterogeneity, the role of Soviet nomenclatura networking. We discuss not only the overall inter-industry wage structure but also the dynamics observed over this time period. Section V draws some conclusions from this paper's results.

\section{Background}

\section{A. Soviet Wage Structure}

Russia is an interesting case with its transition away from plan economy, input hoarding, over-qualification and over-employment to a market based economy. In the Soviet Planned 
Economy wages were largely determined by the central planning authorities. According to Chapman (1979), the earnings of a industrial worker mainly consisted of a basic wage rate reflecting the workers skill level and the responsibilities connected with their work. The classification of workers followed common standards according to the "Unified Wage-Qualification Handbook", which specified the respective skill level and responsibilities that were required for each occupation. The basic wage rates were however allowed to differ between industries. In addition to the basic wage rate, various supplements for working conditions and overtime work were also paid. Moreover, there existed the possibility of regional supplements.

Earnings of salaried employees were determined according to a similar pattern depending on the position's respective skill level and the responsibilities it required. Earnings of salaried employees also differed between industries, thus reflecting the industries' relative importance for the national economy as a whole.

Gregory and Kohlhase (1988) estimated reduced-form earnings equations with standard human capital indicators, industry dummies and indicators of political loyalty for a sample of 2793 former Soviet citizens who immigrated to the United States between 1979 and 1982. Although the respective sample is far from being representative, their findings indeed shed some light on the wage distribution under the Soviet Planning System. By including a set of industry dummies in their estimation, Gregory and Kohlhase (1988) also provide some evidence for the inter-industry wage structure.

In order to assess the inter-industry wage dispersion, we transform the original coefficients, which were initially derived with an arbitrarily chosen reference industry, to deviations from the sample (weighted) average according to Haisken-DeNew and Schmidt (1997). As Table 1 indicates, inter-industry wage dispersion, as measured by the standard deviation of the wage differentials, was quite low in the Soviet System with only 4\%-pts among the highly skilled (70\% of the sample) and 9\%-pts (the remaining 30\% of the sample) among low-skilled employees. This provides us with a benchmark for the analysis of inter-industry wage differentials in Russia's 
Table 1: Soviet Inter-Industry Wage Differentials from Gregory and Kohlhase (1988)

\begin{tabular}{|c|c|c|c|c|c|}
\hline \multicolumn{2}{|c|}{ Industry } & \multicolumn{2}{|c|}{ High Skilled } & \multicolumn{2}{|c|}{ Low Skilled } \\
\hline & Observations & 1349 & - & 591 & - \\
\hline 1 & Manuf: Chemical & 0.05157 & $(1.60)$ & -0.29778 & $(8.35)$ \\
\hline 2 & Manuf: Energy & -0.02162 & $(0.87)$ & 0.20681 & $(5.37)$ \\
\hline 3 & Manuf: Machine Building & 0.09307 & 3.93 & 0.10151 & 2.86 \\
\hline 4 & Manuf: Wood/Building Material & 0.08047 & $0.75)$ & 0.24021 & 6.02 \\
\hline 5 & Manuf: Light, Excluding Food & 0.02137 & $(0.53)$ & -0.02288 & $(0.28$ \\
\hline 6 & Manuf: Light, Food & 0.27407 & $(11.37)$ & -0.07138 & $(1.89$ \\
\hline 7 & Manuf: Other & 0.18197 & $(6.33)$ & 0.00051 & $(0.01$ \\
\hline 8 & Agriculture & 0.14327 & $(5.56)$ & 0.34321 & $(9.49$ \\
\hline 9 & Transportation & 0.07817 & $0.67)$ & 0.05571 & $(0.34$ \\
\hline 10 & Communication & -0.00082 & $0.03)$ & -0.12288 & $(3.29$ \\
\hline 11 & Construction & 0.06597 & $0.50)$ & 0.22721 & $(3.88$ \\
\hline 12 & Trade/Social Catering & -0.01482 & 0.41 & -0.15708 & $(2.99$ \\
\hline 13 & Material and Technical Supply & -0.04832 & $(1.99)$ & -0.12138 & $(3.40$ \\
\hline 14 & Other Productive Services & -0.01352 & $(0.49)$ & -0.42968 & $(12.06$ \\
\hline 15 & Municipal Economy and Housing & 0.02327 & $0.71)$ & 0.01681 & $(0.12$ \\
\hline 16 & Health and Physical Culture & -0.05652 & $(1.08)$ & -0.28358 & $(7.79$ \\
\hline 17 & Education & -0.10742 & $(2.36)$ & -0.24508 & $(6.67$ \\
\hline 18 & Culture and Arts & -0.11582 & $(3.85)$ & -0.07168 & $(1.79)$ \\
\hline 19 & Science & 0.00947 & $(0.13)$ & -0.09848 & $(2.65)$ \\
\hline \multirow[t]{2}{*}{20} & Credit/State and Party & 0.06267 & $(0.81)$ & -0.06448 & $(1.56)$ \\
\hline & Std Dev: Ind & 0.0403 & - & 0.0977 & \\
\hline
\end{tabular}

Important Note: The results presented here have been transformed from the original coefficients using an arbitrary reference category as found in Gregory and Kohlhase (1988) Table 3 and individual industry weights from Table A1 to deviations from the (sample) weighted average, as described in Haisken-DeNew and Schmidt (1997).

current transition process towards a market economy.

\section{B. Wage Setting and the Market Economy}

The Russian labor movement is still dominated by former Soviet trade unions, which are grouped together under the Federation of Independent Trade Unions of Russia (FNPR). The Federation represents over $95 \%$ of the unionized labor force, which is about 50 million people. Kubicek (1996) states that the power of the Federation relies largely on its monopolistic control exerted over social insurance funds and goods such as holiday homes, etc. While the FNPR 
lacks credibility and the trust of its members, it uses the access to these goods and funds as an incentive to retain membership. For this reason, the FNPR also depends upon state recognition and access to property and state funds, which in return constrains its independence and power. Smaller independent unions also exist in Russia, which are estimated to represent around five million workers. However their influence remains limited. The largest employer's organization is the Russian Union of Industrialists and Entrepreneurs (RSPP). Together with its affiliated groups, the RSPP represents over two-thirds of Russia's industrial output.

IWH-Halle, DIW-Berlin, and IfW-Kiel (1998) outline the wage setting institutions established after the move towards the market economy in Russia. In 1990, the "Enterprise Law" guaranteed the independence of wage setting decisions at the firm level, such that wages were indeed set at the firm level for about $70 \%$ of all employees under collective wage contracts. However, often management simply set wages unilaterally due to a lack of collective contracts, or bargained wages were simply not effectively binding. In 1992, "General Contracts" were introduced, with the intention of supplementing the relatively decentralized wage setting system. Their function was primarily to establish a consensus between government, trade unions and employers on the general wage level, social standards and economic reforms, although they were not binding.

The simple idea behind this was to establish a common basis to promote continued provision of social welfare payments by the state, the maintenance of current employment levels by employers and the waiver of strike action by unions. Since 1993 independent unions such as the "Social Trades Union" or the "Independent Miner's Union" have pulled out of the negotiations. The labor side is only represented by the FNPR, whilst the employers' position is largely dominated by the RSPP and its affiliated groups. This results in ineffective representation of workers and employers, in the western sense. The scope of General Contracts was in practice very limited, because no side had actually been able to fulfill its commitments. As Kubicek (1996) puts it, "the state lacks the resources to maintain the social safety net, layoffs and delayed 
wage payments have occurred, and unions have not been able to prevent their members from striking" (p.41).

For firms owned outright or jointly owned by the government, "industry specific contracts" between government, employer associations and the government were also introduced, which regulated general minimum wages, an intricate system of wage indexation (due to the considerable inflation prevalent in the mid 1990's), wage premiums and lay-off rules. In general, these "industry" or "general" contracts depended largely on the importance of the industry and its political influence. The focus was clearly on maintaining employment (job security) and not catering to accelerating wage demands.

In 1992, the "uniform wage schedule system" was also introduced in the public sector with as many as 18 pay groups, and set minimum wages. However, these minimum wages were set so low as not to be binding in any effective way.

\section{Wage Arrears and the Market Economy}

The issue of "wage arrears", i.e. the phenomena of firms not paying their employees in full (or at all) potentially even for years, which affects up to half of all employees, plays an important role in the determination of wages. Table 2 illustrates this problem for the period 1993-2000. If one is concerned with analyzing the wage structure, then one might think that the absence of wages is important. However it should be stressed that wage arrears are part of a general economic arrears phenomenon. According to Ivanova and Wyplosz (1999) total arrears, that is arrears to the consolidated government, private and public wage arrears and arrears to suppliers and banks, amounted to a total of around 35\% of GDP in 1998. As the driving force behind this widespread arrears problem, the authors identify the lack of binding bankruptcy rules in the Russian economy. If payments cannot be enforced, then a circle of ever-increasing mutual arrears results.

On top of these macro-economic forces, the question exists as to whether there are any 
determinants of wage arrears at the firm and individual level . Earle and Sabirianova (2000) and Earle and Sabirianova (1999) examine wage arrears in Russia and outline several hypotheses for their existence. With tax evasion rampant in Russia, the tax authorities attempt to levy taxes directly on wages and profits, giving the firm an incentive to under-report earnings. Thus at the moment a firm becomes solvent enough to pay wages, it obviously can also becomes able to pay potential (back) taxes, leading to an exacerbation of wage payment problems. Acting stategically, the firm may try to gain access to certain "transition" or "recovery" adjustment funds offered by the government, if it can convince the government of its poor economic solvency. An example of successful lobbying for such government funds is the establishment of the so called "30/70 rule" in 1994, which allowed firms with wage arrears to use up to $50 \%$ and later up to $30 \%$ of their liquidity to pay arreared wages instead of taxes. Tax payments are legally deferred and with high inflation rates, this is equal to a substantial permanent tax relief, as discussed in Alfandari and Schaffer (1996). Managers may also have a strong incentive to invest wage expenditures rather on the short-term T-Bill market, which over the course 1994-1996 could exact 30-150\% interest rates, allowing them to pocket the difference. If managers are poorly monitored then this is all the more likely to occur. It also could be the case that unpaid wages have simply become a form of voluntary lending by the employees of newly privatized firms.

Another theory might simply be that firms would like to pay people their marginal product. In the transition period with drastic over-employment in various formerly state owned enterprises, the firm is morally or legally forced not to fire unproductive workers, and tries to compensate for this by "punishing" unproductive workers through wage arrears ${ }^{1}$. This would suggest that only certain workers within a firm and not others experience wage arrears. Some evidence is provided by Lehmann, Wadsworth, and Acquisti (1999) that this is indeed not the case stating, "Industry, region and enterprise characteristics rather than individual characteristics are the main determinants of wage arrears." (p. 14) However this is a difficult issue to

\footnotetext{
${ }^{1}$ Thanks to Christoph M. Schmidt, University of Heidelberg for pointing this out.
} 
address, as there are no publicly available firm employee matched data sets for Russia, in order to identify this effect fully. This issue is however subject to debate, as Earle and Sabirianova (1999) claim that there is indeed some inter-firm as well as intra-firm variation, leading one to believe that individual characteristics such as job tenure, occupation and small share-holding play a role. They find that arrears are positively correlated with firms with monopsony power, and negatively correlated with large share-holding, regional performance, private ownership and the newness of firm.

The question that immediately arises, why would employees tolerate such unpredictable payment behavior of the firms? Why would they not simply quit their jobs and work somewhere else? Earle and Sabirianova (1999) state that those employees who do indeed quit, lose not only their current income, but typically all previous claims to unpaid wages as well facing an uncertain labor market. Many simply cannot afford to quit (and hardly afford to stay). Often these firms not regularly paying wages are large regional monopsonies in "one horse towns", thereby reducing the outside option of their workers. Of course, during the time that wages are not being paid, at least the workers have access to firm fringe benefits and their accustomed social environment at the workplace. There is the simple belief that someday their back pay will actually be paid.

Table 2: Percentage of People with Wage Arrears

\begin{tabular}{|l|l|l|l|l|l|}
\hline Year & 1993 & 1995 & 1997 & 1999 & 2000 \\
\hline Percentage Wage Arrears & 41.93 & 45.31 & 64.34 & 65.35 & 30.83 \\
\hline
\end{tabular}

Source: Authors' calculation on the basis of the RLMS 


\section{Role of Human Capital}

In order to assess inter-industry wage differentials properly, it is important to analyze how people select themselves to high and low-paying industries. In general human capital plays a major role in determining the selection process. To date, however research concerning the wage distribution in Russia suggests that human capital plays a rather weak role. Gregory and Kohlhase (1988) analyze wage premiums for several human capital indicators in the Soviet Planned Economy on the basis of data from the Soviet Interview Project. In general their results suggest that human capital, as indicated by the level of education, only yielded moderate returns in the Soviet Planned Economy. Among workers with high-level earnings, only the completion of higher education raises earnings, by a wage premium of about $22 \%$. Out of this wage premium, about $10 \%$ can be attributed to occupational choice and $12 \%$ to higher earnings within a given occupation. For low-level earnings, only the basic education up to 8 years of schooling yields a wage premium. Beyond this point, any additional education has no relevance for the wage determination. This remains true even for vocational training or specialized secondary education.

However, despite Russia's move to a more market oriented economy, current returns to human capital, as identified by standard human capital indicators, remain fairly low. Newell and Reilly (1996), examining the gender wage gap in present day Russia, find that spartan Mincerian wage equations do not adequately fit Russian data, identifying only moderate returns to education ${ }^{2}$. This may indeed be due to the over-supply of human capital (high skill training) and the traditionally relatively compressed wage structure of the communist regime. Further they find strong evidence for segregated occupations and stress the importance of unobservable determinants in Russian wage setting. However, this analysis only takes into account the information that was available in 1992.

\footnotetext{
${ }^{2}$ However, they find that men have approximately $50 \%$ higher returns to education than women, $90 \%$ of the gap is explained by the returns to characteristics.
} 
With our data that only recently have become available, we are able to analyze human capital returns and the role human capital plays in the selection of individuals into certain industries during Russia's ongoing transition process from the year 1993 until 1999.

\section{Data}

The Russia Longitudinal Monitoring Survey (RLMS) ${ }^{3}$ panel (phase II sample) consists of approximately 4,700 households representing a clustered random sample of the Russian population (Moscow, St. Petersburg and outlying areas are also present in the sample) for 1994, 1995, 1996 and 1998. All adult household members are sampled.

The Russian Socio-Economic Transition Panel (RUSSET) ${ }^{4}$ is a representative longitudinal study of Russian households. It provides information on household composition, satisfaction, employment, earnings, health and political participation. The Panel was started in 1993 and came to an end in 1999.

For our sample, we chose prime-age (18-65) full-time employed males and females, working both in blue and white collar positions. Education is classified by three increasing levels: less than secondary school, secondary school and training and university. Firm size is classified into the following groups: 1-9 persons, 10-24 people, 25-99 people, 100-249 people, 250-999 people, 1000 people and more.

Table 3 shows the industry classification used in the RLMS and RUSSET and the common classification we use to allow direct comparison between the data sets. Occupations were classified as follows: (a) Legislators, Senior Managers, Officials, (b) Professionals, (c) Technicians and Associate Professionals, (d) Clerks, (e) Service workers and market workers, (f) Skilled Agricultural and Fishery workers, (g) Craft and related Trades, (h) Plant and Machine Operators and assembly line workers, (i) Primary (unskilled) occupations, (j) Army. Observations on

\footnotetext{
${ }^{3}$ Managed at CPC, University of North Carolina.

${ }^{4}$ Managed at University of Amsterdam.
} 
Table 3: Industry Classification Outline - RLMS and RUSSET

\begin{tabular}{|c|c|c|}
\hline Common Classification & RLMS & RUSSET \\
\hline Manufacturing & Manufacturing & $\begin{array}{l}\text { Industry Production } \\
\text { PC Hardware/Software }\end{array}$ \\
\hline Construction & Construction & Construction \\
\hline Transport/Communications & $\begin{array}{l}\text { Transportation } \\
\text { Communications }\end{array}$ & Transport, Post and Communications \\
\hline Wholesale/Retail & Trade & $\begin{array}{l}\text { Trade } \\
\text { Retailing }\end{array}$ \\
\hline Housing Utilities & Housing/Utilities & Power, Gas Supply, Water Supply \\
\hline Health & Health & Health Service, Sport \\
\hline Education/Science & $\begin{array}{l}\text { Education } \\
\text { Science }\end{array}$ & $\begin{array}{l}\text { Science } \\
\text { Education }\end{array}$ \\
\hline Government & Government and Public Administration & $\begin{array}{l}\text { Government Services } \\
\text { Communal Services } \\
\text { Public Services } \\
\text { Bar, Court, Public Prosecution } \\
\text { Police } \\
\text { Fire station }\end{array}$ \\
\hline Services & $\begin{array}{l}\text { Personal Services } \\
\text { Professional Services } \\
\text { Entertainment and Recreation } \\
\text { Business and Repair Services }\end{array}$ & $\begin{array}{l}\text { Mass Media } \\
\text { Culture, Art } \\
\text { Services } \\
\text { Other commercial services } \\
\text { Gambling business } \\
\text { Advertising }\end{array}$ \\
\hline Mining/Oil/Gas & $\begin{array}{l}\text { Mining } \\
\text { Oil and Gas Industry }\end{array}$ & Mining \\
\hline Finance/Insurance/Real Estate & Finance/Insurance/Real Estate & Finance, Insurance \\
\hline Dropped & $\begin{array}{l}\text { Military } \\
\text { Agricultural } \\
\text { Forestry Services } \\
\text { Fishing Industry }\end{array}$ & $\begin{array}{l}\text { Army } \\
\text { Agriculture, Forestry, Fishery }\end{array}$ \\
\hline
\end{tabular}

people with army/military and agriculture as an occupation or industry have been eliminated from the analysis.

For the RUSSET data set, regions are defined as follows: (a) North/NorthWestern, (b) Central-Central Black Earth, (c) Volga-Vaytski/Volga Basin, (d) Ural, (e) Western Sibirian, (f) Eastern Sibirian and Far East, (g) Northern Caucasus. In the RLMS, the regional breakdown is identical, except that Moscow and St. Petersburg are also identified.

The role of inflation in Russia is especially important. We deflate all monthly wage information for Russia using the consumer price index provided by DIW-Berlin and Weltwirtschaft-Kiel (2000) from Goskomstat (Statistics Russia) that is differentiated by year and month. 
Table 4: Weighted Employment Shares, by Industry (RUSSET)

\begin{tabular}{lrrrrrrr}
\hline Industry / Year & 88 & 93 & 94 & 95 & 97 & 98 & 99 \\
& & & & & & & \\
\hline Manufacturing & 27.21 & 24.52 & 22.08 & 20.29 & 20.05 & 17.06 & 21.58 \\
Construction & 11.05 & 9.42 & 9.93 & 12.03 & 9.97 & 6.45 & 6.10 \\
Transport/Communication & 11.95 & 10.92 & 12.09 & 12.35 & 11.36 & 11.49 & 12.82 \\
Trade & 5.82 & 8.65 & 8.36 & 10.08 & 10.04 & 9.93 & 8.90 \\
Housing/Utilities & 3.41 & 3.94 & 3.91 & 3.42 & 5.30 & 4.76 & 4.48 \\
Health Service & 7.58 & 6.71 & 7.60 & 7.76 & 7.25 & 8.12 & 8.33 \\
Education/Science & 11.68 & 11.94 & 11.75 & 12.37 & 10.46 & 14.60 & 13.18 \\
Government Sector & 13.40 & 15.34 & 14.52 & 13.16 & 15.67 & 19.09 & 16.75 \\
Service & 2.77 & 2.85 & 3.36 & 2.56 & 3.03 & 3.16 & 3.67 \\
Mining/Oil-Gas & 3.75 & 3.11 & 3.47 & 2.88 & 3.38 & 3.21 & 2.31 \\
Finance & 1.37 & 2.59 & 2.94 & 3.11 & 3.50 & 2.13 & 1.88 \\
& & & & & & & \\
\hline
\end{tabular}

Table 4 shows the employment shares of industries over the time period 1988-1999, reflecting changing demand patterns. Manufacturing has clearly declined dramatically over this period, with the restructuring of Russian heavy industry in the market-based economy.

\section{Application}

\section{A. Differential Mechanics}

As previously mentioned, in order to access the inter-industry wage dispersion, we transform the original coefficients, which were initially derived with an arbitrarily chosen reference industry, to deviations from the sample (weighted) average according to Haisken-DeNew and Schmidt (1997). Thus changes in a reported differential (with respect to the average) contain two components: the untransformed coefficient coming directly out of the regression and the weight attached to it. To isolate the pure effects of returns gained from being in any given industry, we extend the Haisken-DeNew and Schmidt (1997) procedure in such a manner that the weighting vector is fixed for all years, using the RLMS and RUSSET values respectively for 1994. Thus any changes can only be attributed to the changes in relative returns in any particular industry. For more background information, see Schmidt (1998). 
More specifically, we use weights derived from the sample, which includes both persons without arrears (i.e. we observe their wages) and also persons for whom we impute wages. Thus changes in the coefficients reflect only changes in returns, and not simply the fact that those experiencing arrears may be clustered in certain categories. We do this in an analog sense for all other sets of dummy variables such as occupation, firm size, region etc.

\section{B. Industry Wage Structure 1993-1999: Pooled}

For both data sets, we estimate (log) wage regressions, following a standard human capital / job characteristic approach. The RUSSET provides us with information on total monthly income (unfortunately potentially also including asset income) and from the RLMS, we have actual monthly labor income. Despite the fact that many Russians might be very uneasy about revealing their monthly income to a surveying agency (which for many, may simply be viewed as an extension of the government), we believe that these data are the best available. These income/wage indicators are regressed on the explanatory variables described in the data section.

Table 6 (RUSSET) and Table 8 (RLMS) illustrate the scarce returns to education, below the level of university. University education commands a $20 \%$ to $25 \%$ premium when compared to the average, whereas secondary education is actually valued at $5 \%$ to $7 \%$ less than average.

After we control for personal characteristics such as occupation, education, marital status and age, the overall inter-industry wage dispersion indicated by the weighted standard deviation of the industry dummy's coefficients slightly increases. (Compare "Std Dev: Ind" in column (1) at $23.8 \%$-pts and (2) at $25.1 \%$-pts in Table 8 .)

This somewhat puzzling result points to the fact that there is actually a mismatch of human capital across industries. In "normally" behaving economies, one would expect that part of the overall observed wage dispersion can be explained by the selection of certain human capital type individuals into certain industries in which a demand for these human capital types exists. For example, one might expect strong concentrations of highly skilled people to be found in 
the banking sector, and when controlling for this, some of the dispersion would be "explained away". However such a selection of individuals does not seem to take place in Russia. Actually, given the training people do have in such sectors as banking, they indeed earn even more. A likely explanation is that the market simply values human capital, as one might traditionally define it (occupational training, education), less, as the Russian economic transition towards a market economy continues.

Weiss, Sauer, and Gotlibovski (1999) find evidence for this by examining the assimilation process of nominally "highly skilled" Russian immigrants in Israel. There is a speedy entry into the labor force, an initial phase of work in low-skill occupations, a gradual occupational upgrading and a sharp increase in wages. However immigrants simply do not "catch up" with "native" Israelis with regard to wages and employment opportunities, indicating a significant "discounting" of Soviet education.

If human capital becomes obsolete, people select into certain branches on the basis of nonobservable characteristics or just remain in their industry, thus perhaps leading to an unwanted segmentation of the work force. A possible direct explanation for this is the negative mobility effect of wage arrears. Wage arrears are indeed highly prevalent in Russian society, having the effect that persons quitting such jobs would typically forfeit accumulated arrear claims. This is exacerbated by the typically ineffective legal enforcement of wage payments and the relatively strong bargaining position of management.

After we control for NON-personal characteristics such as geographical region, firm size, and an indicator for government ownership of the firm, the overall inter-industry wage dispersion indicated by the weighted standard deviation of the industry dummy's coefficients decreases. (Compare "Std Dev: Ind" in column (1) at 23.8\%-pts and (3) at 20.9\%-pts in Table 8.) This indicates the relative importance of local industrial structure, such as local monopsonies, in a segmented labor market.

Column (4) of Table 6 (RUSSET) and Table 8 (RLMS) describe the structure of wages. 
All sets of dummy variables: industry, occupation, region, firm size, education have overall group dispersion measures reported, thus giving an idea of their overall relative "importance". The standard deviation for industry wage effects is the highest at around $20 \%$ pts. High paying industries include: (a) Mining, Oil and Gas, (b) Finance sector, (c) Transport and Communications, and (d) Housing and Utilities. Payments in the Oil and Gas sector reach levels of $31 \%$ to $46 \%$ higher than average, ceteris paribus. Poorly paying industries include: (a) Health Services, (b) Education and Sciences, and (c) Other Services. Payment in the Education sector is in fact even $32 \%$ to $37 \%$ below average.

Directly comparing our results to those of Gregory and Kohlhase (1988) in Table 1 is somewhat difficult as the industry classification they used is not compatible, due to data limitations. However, Gregory and Kohlhase (1988) use a more disaggregated classification than the paper does, and, as such, one would expect, ceteris paribus, more dispersion between industries and less within. Even though we use a more aggregated classification system, our results consistently show substantially higher levels of inter-industry wage dispersion in both data sets used. Compare Table 1's dispersion results reporting 4\%-points for the high-skilled and 10\%-points for the low-skilled with the industry dispersion of $18 \%$ in Table 6 (RUSSET) and $22 \%$ in Table 8 (RLMS).

This reflects the economic transition process in Russia, where previously planned industrial production is moving towards a market economy, with industry-specific demand and factor prices changing very dynamically in a short period of time.

\section{Industry Specific Returns on Government Ownership}

At one time, all Russian "firms" were owned by the Soviet collective. With increasing moves toward privatization, what role does government ownership now play in determining the structure of wages? Table 6 (RUSSET) and Table 8 (RLMS) show the effect on wages to be negative at $-15 \%$ when compared to private firms. Is this true in all industries? Table 9 clearly demon- 
strates this not to be the case. We simply extend eqn (4) of Table 8 to include a complete set of industry and government ownership interaction terms. We can then calculate the wage differential of a particular industry for those which are government owned ("Gov't" in Table 9) and those which are privately owned ("Private" in Table 9). For each industry, the difference between government and privately owned ("Difference" in Table 9) can be compared to the overall effect of $-14.6 \%$.

Joint F-tests show that the individual industry effects do differ significantly from the overall effect. Furthermore, the government-owned firms in the Oil and Gas industry pay 9\% higher wages than private firms do, but both still pay much better than an average government-owned

firm. In contrast, in general Services, government firms pay much lower wages: some $37 \%$ lower, even lower than the $-14.6 \%$ on average. This latter finding is perhaps not so surprising, as private firms moving into a newly privatized market segment would have a clear economic incentive to pick a strong growth industry, leaving the government with the lemons. Clearly the government profits from the strategic advantage of energy based industries.

\section{Panel Analysis}

As the estimation results of the above person- and non-person specific models indicate, there appears to be some human capital "mismatch". People with relatively higher human capital, as indicated by occupation, education, work experience and age, simply do not select themselves into the higher paying industries. Clearly, this result is puzzling and points to the hypothesis, that it is unobservable person characteristics rather than standard human capital indicators that determine the selection of individuals into high paying industries.

One way to control for individuals' unobservable characteristics is to use a panel model with individual fixed effects. Thereby all observable and non-observable characteristics of a person that do not change over time are captured by a person specific constant. Hence occupational and educational variables only have explanatory power, if they change in the observation period, 
and are otherwise absorbed into the constant.

After we applied such a panel model to our data, the industry wage dispersion reduces substantially from $22.4 \%$-pts to $11.5 \%$-pts. This is evidence for the fact that unobservable positive workers' characteristics help to explain higher than average paying industries. The result confirms our earlier hypothesis that the market values human capital less, as one would traditionally define it, since human capital, which was acquired in the Soviet-period, becomes increasingly obsolete as economic restructuring in Russia proceeds.

However one has to be cautious in over-interpreting the results of the panel analysis due to the well known potential of industry misclassification in panel data, as discussed in Keane (1993). In our case this problem should not be severe, since industries are fairly aggregated and the classification in fact is comparable to a one-digit industry classification scheme. A misinterpretation of a respondents industry data-set-entry would therefore require to misclassify for example the "Manufacturing" industry with the "Education and Science" sector, which seems unlikely to happen.

\section{E. Industry Wage Structure Dynamics}

In order to identify the dynamic changes in the industry wage structure, we also estimate (log) wage regressions for each and every year separately, from 1993 through to 1999 using both data sets.

Table 7 (RUSSET) and Table 10 (RLMS) illustrate the large movements in industry wage premia. High-paying industries such as Oil and Gas seem to be ever increasing, reaching levels of between $59 \%$ and $81 \%$ above average. The Finance sector on the other hand fluctuates between levels of $20 \%$ and $50 \%$ above average. The RUSSET shows a slow but steady increase in the standard deviation of industry differentials from 16.6\%-pts in 1993 to 22.5\%-pts in 1999 . The RLMS also displays a clear picture, with the standard deviation increasing from 18.6\%-pts in 1994 to $27.2 \%$-pts in 1998. 
One interesting aspect of Russia's transition process is the development of the relative earnings position of the former Soviet nomenclatura. Bird, Frick, and Wagner (1998) examine the returns to Socialist Party membership after the Reunification in East Germany up through 1994. However, party membership is not explicitly observed in their dataset, so they proxy this with "having had a telephone in 1990", which at the time was asserted to be correlated with the privilege of party membership. They find that from 1990 through to 1994, having had a telephone yielded a positive income differential of up to $12.5 \%$ even as late as 1994 .

Gregory and Kohlhase (1988) analyze wage premiums with regard to political activity under the Soviet System based on a sample of 2793 former Soviet citizens who immigrated to the United States. In general their results suggest that individuals who had a leading position in system supporting organizations received a substantial reward in form of higher wages. For employees with high-level earnings, Gregory and Kohlhase (1988) estimated a wage premium of $8.8 \%, 2.7 \%$ of which can be attributed to a favorable placement in higher paying occupations. For low-level earnings the wage premium for a leading position in a regime supporting organization was estimated to be $9 \%$, which solely comes in the form of higher pay within a given occupation.

Our interest was to establish, on the basis of a more representative sample of Russian residents, whether being a member of the nomenclatura under the Soviet System indeed paid off in terms of wage premiums and if so, how long into the transition period this effect remained present. The RUSSET survey provides us with some helpful information regarding this. Even though the earliest observation period of the RUSSET is 1993, the questionnaire does contain questions related to the pre-transition year 1988.

In contrast to the approach of Gregory and Kohlhase (1988) and Bird, Frick, and Wagner (1998) we identify former members of the Soviet nomenclatura as those who actually were members of the communist party. Among other things, individuals were asked in the RUSSET survey whether they participated in a political party, group or movement in 1988. Since the 
political system was still dominated by the communist party and virtually no other parties existed in 1988, it is reasonable to assume that members of the communist party can be identified by this question.

Membership in the communist party was quite low. We identify about 110 individuals, about $7.1 \%$ (weighted) of our sample. In general, membership in the communist party involved additional responsibilities at the workplace and was often related to certain managerial functions that are not necessarily captured by the occupation variable. In addition, earlier work by Gregory and Kohlhase (1988) suggests that the Soviet political authorities promoted system stability by setting income incentives. We therefore expect that at least in the pre-transition period, members of the communist party received higher incomes than an otherwise similar employee with a comparable human capital endowment as a "reward".

We are able to empirically analyze income differentials from 1993 onwards, as in Table 5, which is the year of the earliest income observation. Due to the small number of observations, we were unfortunately not able to analyze the membership effect by industry. However in 1993 the coefficient of the respective membership dummy is statistically significant and indicates that having been a member of the communist party in 1988 was still providing benefits in 1993 with an income premium of more than $16 \%$. This remained true until as late as 1995 , when the membership dummy is finally rendered insignificant. We interpret this result as being an indicator of important networking effects among communist party members and the relative slow pace of the economic restructuring in Russia at the beginning of the 1990's. As the transition towards a market economy gained momentum, actual productivity related characteristics of workers became more important and network effects faded away.

\section{F. The Role of Arrears and Imputation}

In the RLMS, the existence of wage arrears is asked in all years. We would like to identify the effect of wage arrears in estimating the industry wage structure. To do this, we can run one 
Table 5: Decreasing Returns to Having Been a Communist Party Member in 1988

\begin{tabular}{ccc}
\hline Year & Differential & t-Statistic \\
\hline 1993 & 0.162 & $(2.30)^{*}$ \\
1994 & 0.187 & $(2.00)^{*}$ \\
1995 & 0.148 & $(1.560)$ \\
1997 & 0.062 & $(0.560)$ \\
1998 & -0.181 & $(-1.51)$ \\
1999 & -0.029 & $(-0.19)$ \\
\hline
\end{tabular}

* indicates significant at $5 \%$ level.

set of results assuming that those observations exhibiting wage arrears are simply deleted and another set where they are imputed. This is however not possible for the RUSSET data set, where arrears are identified only in the last two waves.

To deal with missing observations due to wage arrears, we impute wages using regression techniques. In our case, a simple wage regression is run for each year and predicted wages, based only on complete wage observations, are calculated, while capturing the standard error of the prediction. Based on the characteristics of persons having wage arrears ("missings"), we calculate a predicted portion of wages. We then calculate and randomly assign a stochastic term, based on its distribution of the standard error of the prediction. Both components together (prediction and error term) create an imputed value. We use the simulation procedure from Mander and Clayton (2000) 10 times for each year, allowing us to calculate an average of the 10 different estimates (based on different draws of the random component) and an overall estimate of the variance (comprised of "within" and "between" variance components).

We can therefore compare two models for the RLMS data set: wage differentials based on (a) observations with only complete wage information (arrears observations missing) and (b) valid and imputed observations together. For the RUSSET data set, only option (a) is possible, as arrears are only identified in the last two years.

We present regressions for the RLMS, having imputed wage arrears pooling over the years 
94-98 in Table 11. The idea here is to attempt to reconstruct what wage differentials would have been, had one been able to observe paid wages. In the previous tables, persons with wage arrears are not observed at all in the analysis.

If, however, there is a non-random assignment of wage arrears, based on the criteria that "bad" workers (based on unobservables) are not paid their wages, and "good" workers (based on unobservables) are paid their wages, wages in some groups should be overestimated and, therefore, analyses not taking this into account deliver biased results. We see this in the returns to education coefficients in Table 11. Over the period 1994-1998 and controlling for arrears, we find prima facia evidence of so-called "bad" workers experiencing arrears, as the overall dispersion in the returns to education drops from $11.5 \%$-points to $10.1 \%$-points. For example, a university education yields 19.4\%-pts more than an "average education", however including those observations with imputed wages (arrears), reduces this differential to $16.6 \%$-pts. Thus those with arrears have "bad" unobserved characteristics.

Examining the effects of industry, we find a similar pattern. Overall industry dispersion is reduced from $22.4 \%$-points to $21.1 \%$-points when imputing arrears. The majority of individual industries drop, and by about 6\%-points. The Financial sector drops even by $9 \%$-points. It seems apparent that in those industries with less than $50 \%$ of the employees having wage arrears, such as in the Financial, Oil \& Gas, Services, Government, Wholesale/Retail and Transport sector, selection on unobservables into arrears plays more of a role. In other words, in those industries where arrears are common, "good" and "bad" employees alike, typically receive wage arrears, possibly reflecting the overall industry financial constraints.

\section{Conclusions}

Russia has experienced dramatic and far-reaching changes to its economy since the early 1990's. We capture this in our analysis with two Russian household panel data sets. Due to this 
transition period of flexibilization, where wage setting has effectively been decentralized, we are able to observe large changes in the inter-industry wage structure over this period. Quite notably, this is in stark contrast to Western economies such as the United States or Germany, where movements in the industry structure have been slow, if at all perceptible.

The study shows a substantial amount of instability in the industry differentials. There are several instances of particular industries moving consistently to above average levels, such as the Oil and Gas industry, whereas others have been bouncing around at particularly (high or low) level. There seems to be strong evidence to support the claim that, on the whole, the industry dispersion is becoming wider than what Gregory and Kohlhase (1988) found before the transition period. Further, the networking advantage that the Soviet nomenclatura enjoyed immediately after the fall of communism, exerted an influence up to 1994, when its effect became insignificant.

It is also worth noting that, even though there has been a substantial movement toward privatization, we still observe strong effects of government ownership on wages. Furthermore, we find differential effects by industry.

Moreover, for most of the analysis, standard OLS regression methods were used. However, we quantify the role of unobserved individual heterogeneity. Exploratory evidence suggests that indeed, there are substantial person "fixed-effects", reducing the standard deviation of industry wage differentials by about one-third. This is in keeping with existing literature.

After using regression imputation techniques to calculate wage arrears, we do find some evidence for the hypothesis that those having wage arrears imposed upon them are in some way "negatively selected", giving additional support to Earle and Sabirianova (1999). 


\section{References}

Alfandari, G., And M. Schaffer (1996): "Arrears in the Russian Enterprise Sector," in Enterprise Restructuring and Economic Policy in Russia, ed. by S. Commander, Q.Fan, and M. Schaffer, pp. 87-139. EDI Devolopment Studies, The World Bank, Washington D.C.

Bird, E. J., J. R. Frick, And G. G. Wagner (1998): "The Income of Socialist Upper Classes During the Transition to Capitalism: Evidence from Longitudinal East German Data," Journal of Comparative Economics, 26, 221-225.

Chapman, J. (1979): "Recent Trends in the Soviet Industrial Wage Structure," in Industrial Labor in the USSR, ed. by A. Kahan, and B. Ruble, pp. 151-183. Pergamon Press, New York.

DIW-Berlin, and Weltwirtschaft-Kiel (2000): "The Impact of New Technologies on Wages: Lessons from Matching Panels on Employees and their Firms," Discussion Paper 50/00, Deutsches Institut für Wirtschaftsforschung.

Earle, J. S., and K. K. Sabirianova (1999): "Understanding Wage Arrears in Russia," Discussion Paper 139, SITE, Stockholm School of Economics.

- (2000): "Equilibrium Wage Arrears: A Theoretical and Empirical Analysis of Institutional Lock-In," Discussion Paper 196, IZA-Bonn.

Gibbons, R., And L. Katz (1992): "Does Unmeasured Ability Explain Inter-Industry Wage Differentials ?," Review of Economic Studies, 59, 515-535.

Gregory, P., and J. Kohlhase (1988): "Earning Differentials in the Soviet Union: Evidence From the Soviet Interview Project," Review of Economics and Statistics, 70(1), 23-35.

Haisken-DeNew, J. P., And C. M. Schmidt (1997): "Inter-Industry and Inter-Region Differentials: Mechanics and Interpretation," The Review of Economics and Statistics, $79(3), 516-521$.

Ivanova, N., And C. Wyplosz (1999): "Arrears: The Tide that is Drowning Russia," RECEP Moscow.

IWH-Halle, DIW-Berlin, ANd IFW-Kiel (1998): Zur Wirtschaftlichen Lage Russlands: Krise offenbart Fehler der Wirtschaftspolitik. Halle Institute for Economic Research, Halle. Keane, M. P. (1993): "Individual Heterogeneity and Interindustry Wage Differentials," Journal of Human Resources, 28(1), 134-161.

Krueger, A. B., and L. Summers (1988): "Efficiency Wages and the Inter-Industry Wage Structure," Econometrica, 56, 259-293.

Kubicek, P. (1996): "Variations on a Corporatist Theme: Interest Associations in Post-Soviet Ukraine and Russia," Europe-Asia Studies, 48(1), 27-46.

Lehmann, H., J. Wadsworth, and A. Acquisti (1999): "Grime and Punishment: Job Insecurity and Wage Arrears in the Russian Federation," Journal of Comparative Economics, 27, 595-617.

Mander, A. P., And D. Clayton (2000): "sg116.1: Update to Hotdeck Imputation," Discussion Paper 54, Stata Technical Bulletin.

Murphy, K. M., And F. Welch (1992): "The Structure of Wages," Quarterly Journal of 
Economics, 107(1), 285-326.

Newell, A., And B. Reilly (1996): "The Gender Wage Gap in Russia: Some Empirical Evidence," Labour Economics, 3, 337-356.

Schmidt, C. M. (1998): "On Measuring Discrimination and Convergence," Discussion Paper 259, University of Heidelberg.

Weiss, Y., R. Sauer, And M. Gotlibovski (1999): "Immigration, Search and Lost of Skill," Tel Aviv University. 
Table 6: Wage Regressions: RUSSET Pooled

\begin{tabular}{|c|c|c|c|c|}
\hline & ( 1 ) & $(2)$ & ( 3 ) & $(4)$ \\
\hline Ind: Manufacturing & $\begin{array}{c}-0.081 \\
(-3.490) *\end{array}$ & $\begin{array}{c}-0.043 \\
-1.850)^{*}\end{array}$ & $\begin{array}{c}-0.159 \\
(-5.760)^{*}\end{array}$ & $\begin{array}{c}-0.114 \\
(-4.280) *\end{array}$ \\
\hline Ind: Construction & $\begin{array}{c}0.251 \\
(6.530)^{*}\end{array}$ & $\begin{array}{c}0.197 \\
(5.240)^{*}\end{array}$ & $\begin{array}{c}0.191 \\
(4.990)^{*}\end{array}$ & $\begin{array}{c}0.145 \\
(3.870)^{*}\end{array}$ \\
\hline Ind: Transport, Communications & $\begin{array}{c}0.120 \\
(3.500)^{*}\end{array}$ & $\begin{array}{c}0.159 \\
(4.770)^{*}\end{array}$ & $\begin{array}{c}0.125 \\
(3.740)^{*}\end{array}$ & $\begin{array}{c}0.153 \\
(4.720)^{*}\end{array}$ \\
\hline Ind: Wholesale, Retail & $\begin{array}{l}0.023 \\
(0.580)\end{array}$ & $\begin{array}{c}0.127 \\
(3.190)^{*}\end{array}$ & $\begin{array}{l}-0.017 \\
(-0.410)\end{array}$ & $\begin{array}{c}0.092 \\
(2.250)^{*}\end{array}$ \\
\hline Ind: Housing, Utilities & $\begin{array}{c}0.549 \\
(9.220)^{*}\end{array}$ & $\begin{array}{c}0.467 \\
(8.230)^{*}\end{array}$ & $\begin{array}{c}0.429 \\
(7.380)^{*}\end{array}$ & $\begin{array}{c}0.361 \\
(6.520)^{*}\end{array}$ \\
\hline Ind: Health Services & $\begin{array}{c}-0.227 \\
(-5.390)\end{array}$ & $\begin{array}{c}-0.201 \\
(-4.740)^{*}\end{array}$ & $\begin{array}{c}-0.156 \\
(-3.710)^{*}\end{array}$ & $\begin{array}{c}-0.134 \\
(-3.190)^{*}\end{array}$ \\
\hline Ind: Education, Sciences & $\begin{array}{c}-0.303 \\
(-9.320) *\end{array}$ & $\begin{array}{c}-0.422 \\
(-12.200)^{*}\end{array}$ & $\begin{array}{c}-0.195 \\
(-5.650)^{*}\end{array}$ & $\begin{array}{c}-0.315 \\
(-8.810)^{*}\end{array}$ \\
\hline Ind: Government & $\begin{array}{l}-0.033 \\
(-1.170)\end{array}$ & $\begin{array}{l}0.015 \\
(0.540)\end{array}$ & $\begin{array}{l}0.027 \\
(0.940)\end{array}$ & $\begin{array}{c}0.071 \\
(2.550)^{*}\end{array}$ \\
\hline Ind: Services & $\begin{array}{c}-0.334 \\
(-4.820)^{*}\end{array}$ & $\begin{array}{c}-0.384 \\
(-5.850)^{*}\end{array}$ & $\begin{array}{c}-0.250 \\
(-3.670)^{*}\end{array}$ & $\begin{array}{c}-0.308 \\
(-4.760)^{*}\end{array}$ \\
\hline Ind: Mining, Oil, Gas & $\begin{array}{c}0.509 \\
(7.440)^{*}\end{array}$ & $\begin{array}{c}0.363 \\
(5.590)^{*}\end{array}$ & $\begin{array}{c}0.457 \\
(6.800)^{*}\end{array}$ & $\begin{array}{c}0.312 \\
(4.880)^{*}\end{array}$ \\
\hline Ind: Finance, Insurance, Real Estate & $\begin{array}{c}0.185 \\
(2.230)^{*}\end{array}$ & $\begin{array}{l}0.129 \\
(1.630)\end{array}$ & $\begin{array}{c}0.276 \\
(3.430)^{*}\end{array}$ & $\begin{array}{c}0.206 \\
(2.680)^{*}\end{array}$ \\
\hline Std Dev: Ind & 0.222 & 0.224 & 0.187 & 0.184 \\
\hline Occ: Legislators, Senior Managers, Officials & - & $\begin{array}{c}0.255 \\
(6.120)^{*}\end{array}$ & - & $\begin{array}{c}0.242 \\
(5.980)^{*}\end{array}$ \\
\hline Occ: Professionals & - & $\begin{array}{c}0.136 \\
(4.930)^{*}\end{array}$ & - & $\begin{array}{c}0.123 \\
(4.630)^{*}\end{array}$ \\
\hline Occ: Technicians, Professionals & - & $\begin{array}{l}-0.013 \\
(-0.350)\end{array}$ & - & $\begin{array}{l}-0.018 \\
(-0.490)\end{array}$ \\
\hline Occ: Clerks & - & $\begin{array}{c}-0.135 \\
(-3.710)^{*}\end{array}$ & - & $\begin{array}{c}-0.104 \\
(-2.950)^{*}\end{array}$ \\
\hline Occ: Service, Market workers & - & $\begin{array}{c}-0.103 \\
(-2.020)^{*}\end{array}$ & - & $\begin{array}{c}-0.127 \\
(-2.560)^{*}\end{array}$ \\
\hline Occ: Craft and Related Trades & - & $\begin{array}{c}-0.051 \\
(-2.010)^{*}\end{array}$ & - & $\begin{array}{c}-0.054 \\
(-2.180)\end{array}$ \\
\hline Occ: Plant, Machine Operators, Assemblers & - & $\begin{array}{l}-0.010 \\
(-0.290)\end{array}$ & - & $\begin{array}{l}0.017 \\
0.500)\end{array}$ \\
\hline Occ: Elementary (unskilled) & - & $\begin{array}{c}-0.376 \\
(-7.940)^{*}\end{array}$ & - & $\begin{array}{c}-0.376 \\
(-8.220)^{*}\end{array}$ \\
\hline Std Dev: Occ & - & 0.139 & - & 0.133 \\
\hline Region: Moscow, St. Petersburg & - & - & - & - \\
\hline Region: North, North-West & - & - & $\begin{array}{l}-0.004 \\
(-0.120)\end{array}$ & $\begin{array}{l}-0.011 \\
(-0.360)\end{array}$ \\
\hline Region: Central & - & - & $\begin{array}{c}-0.184 \\
(-10.270)^{*}\end{array}$ & $\begin{array}{c}-0.177 \\
(-10.420) *\end{array}$ \\
\hline Region: Volga & - & - & $\begin{array}{c}-0.280 \\
(-8.170)^{*}\end{array}$ & $\begin{array}{c}-0.273 \\
(-8.340)^{*}\end{array}$ \\
\hline Region: Caucasus & - & - & $\begin{array}{c}0.136 \\
(4.090)^{*}\end{array}$ & $\begin{array}{c}0.075 \\
(2.390)^{*}\end{array}$ \\
\hline Region: Ural & - & - & $\begin{array}{c}-0.045 \\
(-1.810)^{*}\end{array}$ & $\begin{array}{l}-0.021 \\
(-0.900)\end{array}$ \\
\hline Region: West Siberia & - & - & $\begin{array}{c}0.429 \\
(8.890)^{*}\end{array}$ & $\begin{array}{c}0.453 \\
(9.910)^{*}\end{array}$ \\
\hline Region: East Siberia & - & - & $\begin{array}{c}0.390 \\
(12.240)^{*}\end{array}$ & $\left(\begin{array}{c}0.383 \\
(12.700)^{*}\end{array}\right.$ \\
\hline Std Dev: Region & - & - & 0.217 & 0.212 \\
\hline
\end{tabular}


Table 6: Continued...

\begin{tabular}{|c|c|c|c|c|}
\hline & $(1)$ & $(2)$ & $(3)$ & $(4)$ \\
\hline Employees: 1-9 & - & - & $\begin{array}{l}-0.001 \\
(-0.010)\end{array}$ & $\begin{array}{l}-0.006 \\
(-0.170)\end{array}$ \\
\hline Employees: $10-24$ & - & - & $\begin{array}{c}-0.114 \\
(-3.300)^{*}\end{array}$ & $\begin{array}{c}-0.080 \\
(-2.440)^{*}\end{array}$ \\
\hline Employees: 25-99 & - & - & $\begin{array}{c}-0.066 \\
(-2.880)^{*}\end{array}$ & $\begin{array}{c}-0.065 \\
(-2.990) *\end{array}$ \\
\hline Employees: 100-249 & - & - & $\begin{array}{l}0.019 \\
(0.720)\end{array}$ & $\left(\begin{array}{l}0.013 \\
0.510)\end{array}\right.$ \\
\hline Employees: 250-999 & - & - & $\begin{array}{l}0.038 \\
(1.490)\end{array}$ & $\begin{array}{l}0.024 \\
(0.980)\end{array}$ \\
\hline Employees: GE 1000 & - & - & $\begin{array}{c}0.076 \\
(2.750)^{*}\end{array}$ & $\begin{array}{c}0.078 \\
(2.950)^{*}\end{array}$ \\
\hline Std Dev: Employees & - & - & 0.056 & 0.049 \\
\hline Gov't Owned Firm & - & - & $\begin{array}{c}-0.180 \\
(-6.230)^{*}\end{array}$ & $\begin{array}{c}-0.148 \\
(-5.390)^{*}\end{array}$ \\
\hline Education: LT Secondary & - & $\begin{array}{c}-0.230 \\
(-6.260)^{*}\end{array}$ & - & $\begin{array}{c}-0.238 \\
(-6.660)^{*}\end{array}$ \\
\hline Education: Secondary/Training & - & $\begin{array}{c}-0.073 \\
(-6.760)^{*}\end{array}$ & - & $\begin{array}{c}-0.069 \\
(-6.670)^{*}\end{array}$ \\
\hline Education: University & - & $\begin{array}{c}0.256 \\
(10.460)^{*}\end{array}$ & - & $\begin{array}{c}0.251 \\
(10.610)^{*}\end{array}$ \\
\hline Std Dev: Education & - & 0.164 & - & 0.162 \\
\hline Age & - & $\begin{array}{c}0.026 \\
(3.110)^{*}\end{array}$ & - & $\begin{array}{c}0.022 \\
(2.660)^{*}\end{array}$ \\
\hline $\mathrm{Age}^{2}$ & - & $\begin{array}{c}-0.000 \\
(-3.020)^{*}\end{array}$ & - & $\begin{array}{c}-0.000 \\
(-2.640)^{*}\end{array}$ \\
\hline Male & - & $\begin{array}{c}0.376 \\
(13.330)^{*}\end{array}$ & - & $\begin{array}{c}0.367 \\
(13.460)^{*}\end{array}$ \\
\hline Married & - & $\begin{array}{l}-0.030 \\
(-1.100)\end{array}$ & - & $\begin{array}{l}-0.012 \\
(-0.450)\end{array}$ \\
\hline Constant & $\begin{array}{c}7.782 \\
(90.100)^{*}\end{array}$ & $\begin{array}{c}6.931 \\
(36.310)^{*}\end{array}$ & $\begin{array}{c}8.478 \\
(85.710)^{*}\end{array}$ & $\begin{array}{c}7.669 \\
(40.090)^{*}\end{array}$ \\
\hline Year: 1993 & - & - & - & - \\
\hline Year: 1994 & $\begin{array}{c}-0.115 \\
(-2.900)^{*}\end{array}$ & $\begin{array}{c}-0.135 \\
(-3.620)^{*}\end{array}$ & $\begin{array}{c}-0.147 \\
(-3.840)^{*}\end{array}$ & $\begin{array}{c}-0.162 \\
(-4.490) *\end{array}$ \\
\hline Year: 1995 & $\left(\begin{array}{c}-0.510 \\
-12.030)^{*}\end{array}\right.$ & $\left(\begin{array}{c}-0.511 \\
-12.770)^{*}\end{array}\right.$ & $\begin{array}{c}-0.509 \\
(-12.380)^{*}\end{array}$ & $\left(\begin{array}{c}-0.507 \\
-13.070)^{*}\end{array}\right.$ \\
\hline Year: 1997 & $\begin{array}{c}0.230 \\
(6.300)^{*}\end{array}$ & $\begin{array}{c}0.200 \\
(5.770)^{*}\end{array}$ & $\begin{array}{c}0.181 \\
(5.050)^{*}\end{array}$ & $\begin{array}{c}0.159 \\
(4.680)^{*}\end{array}$ \\
\hline Year: 1998 & $\left(\begin{array}{c}-0.647 \\
(-15.730)^{*}\end{array}\right.$ & $\left(\begin{array}{c}-0.652 \\
(-16.700) *\end{array}\right.$ & $\begin{array}{c}-0.681 \\
(-16.960) *\end{array}$ & $\left(\begin{array}{c}-0.677 \\
-17.790)^{*}\end{array}\right.$ \\
\hline Year: 1999 & $\left(\begin{array}{c}-0.644 \\
(-15.180) *\end{array}\right.$ & $\left(\begin{array}{c}-0.640 \\
(-15.810)^{*}\end{array}\right.$ & $\begin{array}{c}-0.674 \\
(-16.310)^{*}\end{array}$ & $\left(\begin{array}{c}-0.666 \\
(-16.890)^{*}\end{array}\right.$ \\
\hline $\begin{array}{l}\text { Observations } \\
\mathrm{R}^{2}\end{array}$ & $\begin{array}{c}5935 \\
0.1563\end{array}$ & $\begin{array}{c}5935 \\
0.2518\end{array}$ & $\begin{array}{c}5935 \\
0.2158\end{array}$ & $\begin{array}{c}5935 \\
0.3055\end{array}$ \\
\hline
\end{tabular}


Table 7: Wage Regressions: RUSSET: By Year

\begin{tabular}{|c|c|c|c|c|c|c|}
\hline & $(93)$ & $(94)$ & $(95)$ & $(97)$ & $(98)$ & $(99)$ \\
\hline Ind: Manufacturing & $\begin{array}{c}-0.145 \\
(-3.710)^{*}\end{array}$ & $\begin{array}{c}-0.136 \\
(-2.770)^{*}\end{array}$ & $\begin{array}{l}-0.081 \\
(-1.470)\end{array}$ & $\begin{array}{l}-0.031 \\
(-0.290)\end{array}$ & $\begin{array}{c}-0.135 \\
(-2.430)^{*}\end{array}$ & $\begin{array}{l}-0.092 \\
(-1.490)\end{array}$ \\
\hline Ind: Construction & $\begin{array}{l}-0.004 \\
(-0.080)\end{array}$ & $\begin{array}{l}0.037 \\
(0.530)\end{array}$ & $\begin{array}{c}0.204 \\
(2.980)^{*}\end{array}$ & $\begin{array}{c}0.305 \\
(2.210)^{*}\end{array}$ & $\begin{array}{c}0.228 \\
(2.860)^{*}\end{array}$ & $\begin{array}{l}0.081 \\
(0.840)\end{array}$ \\
\hline Ind: Transport, Communications & $\begin{array}{c}0.108 \\
(2.220)^{*}\end{array}$ & $\begin{array}{c}0.176 \\
(2.990)^{*}\end{array}$ & $\begin{array}{c}0.239 \\
(3.700)^{*}\end{array}$ & $\left.\begin{array}{l}0.060 \\
(0.490\end{array}\right)$ & $\begin{array}{c}0.213 \\
(2.910)^{*}\end{array}$ & $\begin{array}{c}0.223 \\
(3.080)^{*}\end{array}$ \\
\hline Ind: Wholesale, Retail & $\begin{array}{c}0.160 \\
(2.550)^{*}\end{array}$ & $\begin{array}{l}0.005 \\
(0.060)\end{array}$ & $\begin{array}{l}0.074 \\
(0.910)\end{array}$ & $\begin{array}{l}0.082 \\
(0.570)\end{array}$ & $\begin{array}{l}0.050 \\
(0.520)\end{array}$ & $\begin{array}{l}-0.036 \\
(-0.320)\end{array}$ \\
\hline Ind: Housing, Utilities & $\begin{array}{c}0.507 \\
(6.080)^{*}\end{array}$ & $\begin{array}{l}0.064 \\
(0.620)\end{array}$ & $\begin{array}{l}0.125 \\
(0.960)\end{array}$ & $\begin{array}{c}0.468 \\
(2.390)^{*}\end{array}$ & $\begin{array}{c}0.605 \\
(5.050)^{*}\end{array}$ & $\begin{array}{c}0.305 \\
(2.530)^{*}\end{array}$ \\
\hline Ind: Health Services & $\begin{array}{l}-0.050 \\
(-0.750)\end{array}$ & $\begin{array}{l}-0.012 \\
(-0.150)\end{array}$ & $\begin{array}{c}-0.180 \\
(-2.120)^{*}\end{array}$ & $\begin{array}{l}-0.177 \\
(-1.170)\end{array}$ & $\begin{array}{c}-0.252 \\
(-2.940)^{*}\end{array}$ & $\begin{array}{c}-0.212 \\
(-2.120)^{*}\end{array}$ \\
\hline Ind: Education, Sciences & $\begin{array}{c}-0.203 \\
(-3.850)\end{array}$ & $\begin{array}{c}-0.263 \\
(-3.830)^{*}\end{array}$ & $\begin{array}{c}-0.302 \\
(-4.090)^{*}\end{array}$ & $\begin{array}{c}-0.399 \\
(-3.010)^{*}\end{array}$ & $\begin{array}{c}-0.318 \\
(-4.200)^{*}\end{array}$ & $\begin{array}{c}-0.459 \\
(-5.410)^{*}\end{array}$ \\
\hline Ind: Government & $\begin{array}{l}-0.016 \\
(-0.350)\end{array}$ & $\begin{array}{c}0.166 \\
(2.930)^{*}\end{array}$ & $\begin{array}{l}0.027 \\
(0.470)\end{array}$ & $\begin{array}{l}0.069 \\
(0.670)\end{array}$ & $\begin{array}{l}0.007 \\
(0.120)\end{array}$ & $\begin{array}{c}0.135 \\
(2.210)^{*}\end{array}$ \\
\hline Ind: Services & $\begin{array}{l}-0.123 \\
(-1.190)\end{array}$ & $\begin{array}{c}-0.304 \\
(-2.460)^{*}\end{array}$ & $\begin{array}{c}-0.269 \\
(-1.920)^{*}\end{array}$ & $\begin{array}{c}-0.520 \\
(-2.360)^{*}\end{array}$ & $\begin{array}{c}-0.321 \\
(-2.380)^{*}\end{array}$ & $\begin{array}{l}-0.123 \\
(-0.910)\end{array}$ \\
\hline Ind: Mining, Oil, Gas & $\begin{array}{c}0.394 \\
(3.750)^{*}\end{array}$ & $\begin{array}{c}0.210 \\
(1.840)^{*}\end{array}$ & $\begin{array}{c}0.213 \\
(1.700)^{*}\end{array}$ & $\begin{array}{l}0.209 \\
(0.980)\end{array}$ & $\begin{array}{c}0.396 \\
(3.130)^{*}\end{array}$ & $\begin{array}{c}0.594 \\
(3.390)^{*}\end{array}$ \\
\hline Ind: Finance, Insurance, Real Estate & $\begin{array}{c}0.196 \\
(1.780)^{*}\end{array}$ & $\begin{array}{c}0.421 \\
(3.070)^{*}\end{array}$ & $\begin{array}{l}0.158 \\
(1.060)\end{array}$ & $\begin{array}{l}0.125 \\
(0.490)\end{array}$ & $\begin{array}{l}0.156 \\
(0.810)\end{array}$ & $\begin{array}{l}0.328 \\
(1.370)\end{array}$ \\
\hline Std Dev: Ind & 0.166 & 0.155 & 0.159 & 0.179 & 0.223 & 0.225 \\
\hline Occ: Legislators, Senior Managers, Officials & $\begin{array}{c}0.242 \\
(3.850)^{*}\end{array}$ & $\begin{array}{c}0.173 \\
(2.230)^{*}\end{array}$ & $\begin{array}{c}0.323 \\
(3.760)^{*}\end{array}$ & $\begin{array}{c}0.271 \\
(1.990)^{*}\end{array}$ & $\begin{array}{l}0.106 \\
(1.150)\end{array}$ & $\begin{array}{c}0.312 \\
(3.540)^{*}\end{array}$ \\
\hline Occ: Professionals & $\begin{array}{c}0.086 \\
(2.190)^{*}\end{array}$ & $\begin{array}{l}0.072 \\
(1.470)\end{array}$ & $\begin{array}{c}0.103 \\
(1.820)^{*}\end{array}$ & $\begin{array}{c}0.212 \\
(2.280)^{*}\end{array}$ & $\begin{array}{c}0.181 \\
(3.100)^{*}\end{array}$ & $\begin{array}{c}0.201 \\
(2.770)^{*}\end{array}$ \\
\hline Occ: Technicians, Professionals & $\begin{array}{c}-0.095 \\
(-1.750)^{*}\end{array}$ & $\begin{array}{l}-0.017 \\
(-0.220)\end{array}$ & $\begin{array}{l}-0.059 \\
(-0.800)\end{array}$ & $\begin{array}{l}-0.031 \\
(-0.240)\end{array}$ & $\begin{array}{l}0.049 \\
(0.650)\end{array}$ & $\begin{array}{l}-0.055 \\
(-0.630)\end{array}$ \\
\hline Occ: Clerks & $\begin{array}{c}-0.145 \\
(-2.650)^{*}\end{array}$ & $\begin{array}{c}-0.215 \\
(-2.970)^{*}\end{array}$ & $\begin{array}{c}-0.155 \\
(-1.980)^{*}\end{array}$ & $\begin{array}{l}-0.075 \\
(-0.580)\end{array}$ & $\begin{array}{l}0.022 \\
(0.310)\end{array}$ & $\begin{array}{l}0.041 \\
(0.580)\end{array}$ \\
\hline Occ: Service, Market workers & $\begin{array}{c}0.132 \\
(1.550)\end{array}$ & $\begin{array}{l}-0.084 \\
(-0.800)\end{array}$ & $\begin{array}{l}-0.047 \\
(-0.440)\end{array}$ & $\begin{array}{l}-0.199 \\
(-1.200)\end{array}$ & $\begin{array}{c}-0.259 \\
(-2.460)^{*}\end{array}$ & $\begin{array}{c}-0.216 \\
(-1.890)^{*}\end{array}$ \\
\hline Occ: Craft and Related Trades & $\begin{array}{l}-0.001 \\
(-0.030)\end{array}$ & $\begin{array}{l}0.035 \\
(0.770)\end{array}$ & $\begin{array}{l}-0.030 \\
(-0.610)\end{array}$ & $\begin{array}{c}-0.196 \\
(-2.120)^{*}\end{array}$ & $\begin{array}{l}-0.065 \\
(-1.190)\end{array}$ & $\begin{array}{c}-0.172 \\
(-2.640)^{*}\end{array}$ \\
\hline Occ: Plant, Machine Operators, Assemblers & $\begin{array}{l}0.023 \\
(0.450)\end{array}$ & $\begin{array}{l}0.065 \\
(1.030)\end{array}$ & $\begin{array}{l}-0.002 \\
(-0.030)\end{array}$ & $\left.\begin{array}{l}0.071 \\
(0.600)\end{array}\right)$ & $\begin{array}{l}-0.049 \\
(-0.720)\end{array}$ & $\left(\begin{array}{l}0.001 \\
0.010)\end{array}\right)$ \\
\hline Occ: Elementary (unskilled) & $\begin{array}{c}-0.475 \\
(-6.380)^{*}\end{array}$ & $\begin{array}{c}-0.418 \\
(-4.550)^{*}\end{array}$ & $\begin{array}{c}-0.371 \\
(-3.770)^{*}\end{array}$ & $\begin{array}{l}-0.254 \\
(-1.490)\end{array}$ & $\begin{array}{c}-0.465 \\
(-5.500)^{*}\end{array}$ & $\begin{array}{c}-0.357 \\
(-3.920)^{*}\end{array}$ \\
\hline Std Dev: Occ & 0.141 & 0.122 & 0.128 & 0.141 & 0.145 & 0.170 \\
\hline Region: Moscow, St. Petersburg & - & - & - & - & - & - \\
\hline Region: North, North-West & $\begin{array}{l}-0.015 \\
(-0.320)\end{array}$ & $\begin{array}{c}0.117 \\
(1.890)^{*}\end{array}$ & $\begin{array}{l}0.018 \\
(0.260)\end{array}$ & $\begin{array}{l}-0.166 \\
(-1.340)\end{array}$ & $\begin{array}{l}0.032 \\
(0.500)\end{array}$ & $\begin{array}{l}-0.033 \\
(-0.510)\end{array}$ \\
\hline Region: Central & $\begin{array}{c}-0.276 \\
(-10.990)^{*}\end{array}$ & $\begin{array}{c}-0.167 \\
(-5.580)^{*}\end{array}$ & $\begin{array}{c}-0.125 \\
(-3.860)^{*}\end{array}$ & $\begin{array}{c}-0.114 \\
(-1.700)^{*}\end{array}$ & $\begin{array}{c}-0.155 \\
(-4.320)^{*}\end{array}$ & $\begin{array}{c}-0.131 \\
(-3.150)^{*}\end{array}$ \\
\hline Region: Volga & $\begin{array}{c}-0.242 \\
(-4.690)^{*}\end{array}$ & $\begin{array}{c}-0.167 \\
(-1.900)^{*}\end{array}$ & $\begin{array}{c}-0.141 \\
(-2.060)^{*}\end{array}$ & $\begin{array}{c}-0.496 \\
(-4.730)^{*}\end{array}$ & $\begin{array}{l}-0.027 \\
(-0.420)\end{array}$ & $\begin{array}{c}-0.267 \\
(-3.890)^{*}\end{array}$ \\
\hline Region: Caucasus & $\begin{array}{c}0.164 \\
(3.450)^{*}\end{array}$ & $\begin{array}{c}-0.184 \\
(-3.130)^{*}\end{array}$ & $\begin{array}{c}-0.151 \\
(-2.130)^{*}\end{array}$ & $\begin{array}{c}0.387 \\
(3.510)^{*}\end{array}$ & $\begin{array}{c}-0.111 \\
(-1.730)^{*}\end{array}$ & $\begin{array}{l}-0.045 \\
(-0.560)\end{array}$ \\
\hline Region: Ural & $\begin{array}{l}0.037 \\
(1.060)\end{array}$ & $\begin{array}{l}-0.060 \\
(-1.380)\end{array}$ & $\begin{array}{c}-0.172 \\
(-3.900)^{*}\end{array}$ & $\begin{array}{l}0.006 \\
(0.060)\end{array}$ & $\begin{array}{l}-0.043 \\
(-0.890)\end{array}$ & $\begin{array}{l}-0.012 \\
(-0.220)\end{array}$ \\
\hline Region: West Siberia & $\begin{array}{c}0.514 \\
(7.320)^{*}\end{array}$ & $\begin{array}{c}0.468 \\
(5.590)^{*}\end{array}$ & $\begin{array}{c}0.194 \\
(1.780)^{*}\end{array}$ & $\begin{array}{c}0.442 \\
(3.140)^{*}\end{array}$ & $\begin{array}{c}0.600 \\
(5.430)^{*}\end{array}$ & $\begin{array}{c}0.455 \\
(3.960)^{*}\end{array}$ \\
\hline Region: East Siberia & $\begin{array}{c}0.444 \\
(9.070)^{*}\end{array}$ & $\begin{array}{c}0.513 \\
(8.690)^{*}\end{array}$ & $\begin{array}{c}0.761 \\
(10.910)^{*}\end{array}$ & $\begin{array}{l}0.086 \\
(0.830)\end{array}$ & $\begin{array}{c}0.310 \\
(5.290)^{*}\end{array}$ & $\begin{array}{c}0.375 \\
(5.830)^{*}\end{array}$ \\
\hline Std Dev: Region & 0.266 & 0.243 & 0.285 & 0.208 & 0.202 & 0.189 \\
\hline
\end{tabular}


Table 7: Continued...

\begin{tabular}{|c|c|c|c|c|c|c|}
\hline & $(93)$ & $(94)$ & $(95)$ & $(97)$ & $(98)$ & $(99)$ \\
\hline Employees: 1-9 & $\begin{array}{c}-0.186 \\
(-3.080)^{*}\end{array}$ & $\begin{array}{c}-0.204 \\
(-2.860)^{*}\end{array}$ & $\begin{array}{l}-0.029 \\
(-0.400)\end{array}$ & $\begin{array}{c}0.415 \\
(3.080)^{*}\end{array}$ & $\begin{array}{l}0.054 \\
(0.650)\end{array}$ & $\begin{array}{c}-0.193 \\
(-2.210) *\end{array}$ \\
\hline Employees: $10-24$ & $\begin{array}{c}-0.107 \\
(-2.150)^{*}\end{array}$ & $\begin{array}{c}-0.115 \\
(-1.870)^{*}\end{array}$ & $\begin{array}{c}-0.230 \\
(-3.400)^{*}\end{array}$ & $\begin{array}{c}0.132 \\
(1.160)\end{array}$ & $\begin{array}{c}-0.127 \\
(-1.880)\end{array}$ & $\begin{array}{c}-0.156 \\
(-1.920)^{*}\end{array}$ \\
\hline Employees: 25-99 & $\begin{array}{c}-0.032 \\
(-0.950)\end{array}$ & $\begin{array}{c}0.076 \\
(1.770)^{*}\end{array}$ & $\begin{array}{c}-0.091 \\
(-2.100)^{*}\end{array}$ & $\begin{array}{c}-0.170 \\
(-2.120)^{*}\end{array}$ & $\begin{array}{c}-0.065 \\
(-1.450)\end{array}$ & $\begin{array}{c}-0.080 \\
(-1.660) *\end{array}$ \\
\hline Employees: 100-249 & $\begin{array}{l}0.055 \\
(1.420)\end{array}$ & $\left(\begin{array}{l}-0.021 \\
(-0.440)\end{array}\right.$ & $\begin{array}{l}-0.010 \\
(-0.180)\end{array}$ & $\left.\begin{array}{l}0.040 \\
(0.440)\end{array}\right)$ & $\left(\begin{array}{l}0.004 \\
0.080)\end{array}\right)$ & $\begin{array}{l}0.017 \\
0.310)\end{array}$ \\
\hline Employees: 250-999 & $\begin{array}{l}0.005 \\
(0.150)\end{array}$ & $\begin{array}{l}0.014 \\
(0.320)\end{array}$ & $\begin{array}{c}0.150 \\
(2.950)^{*}\end{array}$ & $\begin{array}{l}-0.098 \\
(-1.060)\end{array}$ & $\begin{array}{l}0.008 \\
(0.160)\end{array}$ & $\begin{array}{c}0.185 \\
(3.510)^{*}\end{array}$ \\
\hline Employees: GE 1000 & $\begin{array}{c}0.113 \\
(2.960)^{*}\end{array}$ & $\begin{array}{l}0.069 \\
(1.480)\end{array}$ & $\begin{array}{c}0.097 \\
(1.820)^{*}\end{array}$ & $\left(\begin{array}{l}-0.013 \\
-0.120)\end{array}\right.$ & $\begin{array}{l}0.098 \\
(1.640)\end{array}$ & $\begin{array}{l}0.062 \\
(1.020)\end{array}$ \\
\hline Std Dev: Employees & 0.079 & 0.071 & 0.105 & 0.126 & 0.042 & 0.105 \\
\hline Gov't Owned Firm & $\begin{array}{c}-0.147 \\
(-3.570)^{*}\end{array}$ & $\begin{array}{l}-0.075 \\
(-1.520)\end{array}$ & $\begin{array}{c}-0.161 \\
(-2.990)^{*}\end{array}$ & $\begin{array}{l}-0.159 \\
(-1.520)\end{array}$ & $\begin{array}{c}-0.139 \\
(-2.270)^{*}\end{array}$ & $\begin{array}{c}-0.198 \\
(-2.850)^{*}\end{array}$ \\
\hline Education: LT Secondary & $\begin{array}{c}-0.302 \\
(-5.900)^{*}\end{array}$ & $\begin{array}{c}-0.269 \\
(-3.990)^{*}\end{array}$ & $\begin{array}{c}-0.263 \\
(-3.580)^{*}\end{array}$ & $\begin{array}{l}-0.211 \\
(-1.560)\end{array}$ & $\begin{array}{l}-0.064 \\
(-0.850)\end{array}$ & $\begin{array}{c}-0.145 \\
(-1.650)^{*}\end{array}$ \\
\hline Education: Secondary/Training & $\begin{array}{l}-0.005 \\
(-0.330)\end{array}$ & $\begin{array}{c}-0.041 \\
(-2.080)^{*}\end{array}$ & $\left(\begin{array}{l}-0.028 \\
(-1.270)\end{array}\right.$ & $\begin{array}{c}-0.152 \\
(-4.110)^{*}\end{array}$ & $\begin{array}{c}-0.081 \\
(-3.670)^{*}\end{array}$ & $\begin{array}{c}-0.083 \\
(-3.330)^{*}\end{array}$ \\
\hline Education: University & $\begin{array}{c}0.134 \\
(3.740)^{*}\end{array}$ & $\begin{array}{c}0.201 \\
(4.470)^{*}\end{array}$ & $\begin{array}{c}0.169 \\
(3.320)^{*}\end{array}$ & $\begin{array}{c}0.426 \\
(5.220)^{*}\end{array}$ & $\begin{array}{c}0.206 \\
(4.060)^{*}\end{array}$ & $\begin{array}{c}0.245 \\
(4.310)^{*}\end{array}$ \\
\hline Std Dev: Education & 0.120 & 0.137 & 0.120 & 0.254 & 0.121 & 0.145 \\
\hline Age & $\begin{array}{c}0.031 \\
(2.750)^{*}\end{array}$ & $\begin{array}{c}0.031 \\
(2.010)^{*}\end{array}$ & $\begin{array}{l}-0.020 \\
(-1.130)\end{array}$ & $\begin{array}{l}0.020 \\
(0.640)\end{array}$ & $\begin{array}{l}-0.001 \\
(-0.040)\end{array}$ & $\begin{array}{l}0.024 \\
(1.190)\end{array}$ \\
\hline $\mathrm{Age}^{2}$ & $\begin{array}{c}-0.000 \\
(-2.590)^{*}\end{array}$ & $\begin{array}{c}-0.000 \\
(-1.860)^{*}\end{array}$ & $\begin{array}{l}0.000 \\
(1.240)\end{array}$ & $\begin{array}{c}-0.000 \\
(-0.960)\end{array}$ & $\begin{array}{l}0.000 \\
(0.110)\end{array}$ & $\begin{array}{c}-0.000 \\
(-1.050)\end{array}$ \\
\hline Male & $\begin{array}{c}0.376 \\
(9.140)^{*}\end{array}$ & $\begin{array}{c}0.319 \\
(6.140)^{*}\end{array}$ & $\begin{array}{c}0.346 \\
(6.130)^{*}\end{array}$ & $\begin{array}{c}0.453 \\
(4.640)^{*}\end{array}$ & $\begin{array}{c}0.268 \\
(4.620)^{*}\end{array}$ & $\begin{array}{c}0.388 \\
(6.170)^{*}\end{array}$ \\
\hline Married & $\left(\begin{array}{l}0.016 \\
0.390)\end{array}\right)$ & $\begin{array}{l}-0.038 \\
(-0.740)\end{array}$ & $\left(\begin{array}{l}0.071 \\
1.310)\end{array}\right.$ & $\begin{array}{l}-0.108 \\
(-1.110)\end{array}$ & $\left(\begin{array}{l}-0.006 \\
(-0.110)\end{array}\right.$ & $\begin{array}{l}-0.090 \\
(-1.500)\end{array}$ \\
\hline Work Experience & - & - & - & - & - & - \\
\hline Constant & $\begin{array}{c}7.307 \\
(27.620)^{*}\end{array}$ & $\begin{array}{c}7.525 \\
(21.140)^{*}\end{array}$ & $\begin{array}{c}8.143 \\
(19.740)^{*}\end{array}$ & $\begin{array}{c}7.946 \\
(11.260)^{*}\end{array}$ & $\begin{array}{c}7.201 \\
(15.930)^{*}\end{array}$ & $\begin{array}{c}7.061 \\
(13.840)^{*}\end{array}$ \\
\hline $\begin{array}{l}\text { Observations } \\
\mathrm{R}^{2}\end{array}$ & $\begin{array}{c}1576 \\
0.3494\end{array}$ & $\begin{array}{c}951 \\
0.3084\end{array}$ & $\begin{array}{c}734 \\
0.4176\end{array}$ & $\begin{array}{c}1144 \\
0.1816\end{array}$ & $\begin{array}{c}814 \\
0.3215\end{array}$ & $\begin{array}{c}716 \\
0.3715\end{array}$ \\
\hline
\end{tabular}


Table 8: Wage Regressions: RLMS Pooled

\begin{tabular}{|c|c|c|c|c|}
\hline & $(1)$ & $(2)$ & $(3)$ & $(4)$ \\
\hline Ind: Manufacturing & $\begin{array}{c}-0.049 \\
(-2.850)^{*}\end{array}$ & $\begin{array}{c}-0.035 \\
(-2.040)^{*}\end{array}$ & $\begin{array}{c}-0.107 \\
(-5.750)^{*}\end{array}$ & $\begin{array}{c}-0.075 \\
(-4.060)^{*}\end{array}$ \\
\hline Ind: Construction & $\begin{array}{c}0.304 \\
(8.620)^{*}\end{array}$ & $\begin{array}{c}0.246 \\
(7.100)^{*}\end{array}$ & $\begin{array}{c}0.254 \\
(7.490)^{*}\end{array}$ & $\begin{array}{c}0.202 \\
(6.060)^{*}\end{array}$ \\
\hline Ind: Transport, Communications & $\begin{array}{c}0.230 \\
(7.900)^{*}\end{array}$ & $\begin{array}{c}0.235 \\
(8.180)^{*}\end{array}$ & $\begin{array}{c}0.224 \\
(8.070)^{*}\end{array}$ & $\begin{array}{c}0.238 \\
(8.640)^{*}\end{array}$ \\
\hline Ind: Wholesale, Retail & $\begin{array}{l}-0.037 \\
(-1.360)\end{array}$ & $\begin{array}{c}0.093 \\
(3.050)^{*}\end{array}$ & $\begin{array}{l}0.025 \\
(0.860)\end{array}$ & $\begin{array}{c}0.124 \\
(3.980)^{*}\end{array}$ \\
\hline Ind: Housing, Utilities & $\begin{array}{c}0.090 \\
(2.390)\end{array}$ & $\begin{array}{c}0.123 \\
(3.390)^{*}\end{array}$ & $\begin{array}{c}0.072 \\
(2.020)^{*}\end{array}$ & $\begin{array}{c}0.095 \\
(2.730)^{*}\end{array}$ \\
\hline Ind: Health Services & $\left(\begin{array}{c}-0.367 \\
(-10.610)^{*}\end{array}\right.$ & $\left(\begin{array}{c}-0.382 \\
(-11.040)^{*}\end{array}\right.$ & $\begin{array}{c}-0.313 \\
(-9.370)^{*}\end{array}$ & $\begin{array}{c}-0.325 \\
(-9.730)^{*}\end{array}$ \\
\hline Ind: Education, Sciences & $\left(\begin{array}{c}-0.327 \\
-13.240)^{*}\end{array}\right.$ & $\left(\begin{array}{c}-0.416 \\
-16.140)^{*}\end{array}\right.$ & $\left(\begin{array}{c}-0.271 \\
-11.010)^{*}\end{array}\right.$ & $\begin{array}{c}-0.370 \\
(-14.480)^{*}\end{array}$ \\
\hline Ind: Government & $\begin{array}{c}0.078 \\
(2.210)^{*}\end{array}$ & $\begin{array}{l}0.042 \\
(1.180)\end{array}$ & $\begin{array}{c}0.170 \\
(4.960)^{*}\end{array}$ & $\begin{array}{c}0.127 \\
(3.700)^{*}\end{array}$ \\
\hline Ind: Services & $\begin{array}{l}-0.054 \\
(-1.640)\end{array}$ & $\left(\begin{array}{l}-0.043 \\
-1.380)\end{array}\right.$ & $\begin{array}{l}-0.030 \\
(-0.950)\end{array}$ & $\left(\begin{array}{l}-0.032 \\
-1.040)\end{array}\right.$ \\
\hline Ind: Mining, Oil, Gas & $\begin{array}{c}0.636 \\
(12.540)^{*}\end{array}$ & $\begin{array}{c}0.608 \\
(12.530)^{*}\end{array}$ & $\begin{array}{c}0.476 \\
(9.590)^{*}\end{array}$ & $\begin{array}{c}0.465 \\
(9.780)^{*}\end{array}$ \\
\hline Ind: Finance, Insurance, Real Estate & $\begin{array}{c}0.419 \\
(5.820)^{*}\end{array}$ & $\begin{array}{c}0.413 \\
(5.990)^{*}\end{array}$ & $\begin{array}{c}0.462 \\
(6.750)^{*}\end{array}$ & $\begin{array}{c}0.450 \\
(6.820)^{*}\end{array}$ \\
\hline Std Dev: Ind & 0.238 & 0.251 & 0.209 & 0.224 \\
\hline Occ: Legislators, Senior Managers, Officials & - & $\begin{array}{c}0.256 \\
(3.720)^{*}\end{array}$ & - & $\begin{array}{c}0.292 \\
(4.450)^{*}\end{array}$ \\
\hline Occ: Professionals & - & $\begin{array}{c}0.164 \\
(6.830)^{*}\end{array}$ & - & $\begin{array}{c}0.167 \\
(7.300)^{*}\end{array}$ \\
\hline Occ: Technicians, Professionals & - & $\begin{array}{c}0.086 \\
(3.760)^{*}\end{array}$ & - & $\begin{array}{c}0.070 \\
(3.220)^{*}\end{array}$ \\
\hline Occ: Clerks & - & $\begin{array}{c}-0.148 \\
(-4.300)^{*}\end{array}$ & - & $\begin{array}{c}-0.151 \\
(-4.600)^{*}\end{array}$ \\
\hline Occ: Service, Market workers & - & $\begin{array}{c}-0.083 \\
(-2.300)^{*}\end{array}$ & - & $\begin{array}{c}-0.089 \\
(-2.570)^{*}\end{array}$ \\
\hline Occ: Craft and Related Trades & - & $\begin{array}{c}-0.041 \\
(-1.740)^{*}\end{array}$ & - & $\begin{array}{l}-0.025 \\
(-1.100)\end{array}$ \\
\hline Occ: Plant, Machine Operators, Assemblers & - & $\begin{array}{l}-0.032 \\
(-1.400)\end{array}$ & - & $\begin{array}{c}-0.040 \\
(-1.810)^{*}\end{array}$ \\
\hline Occ: Elementary (unskilled) & - & $\begin{array}{c}-0.286 \\
(-8.980)^{*}\end{array}$ & - & $\begin{array}{c}-0.281 \\
(-9.270)^{*}\end{array}$ \\
\hline Std Dev: Occ & - & 0.127 & - & 0.126 \\
\hline Region: Moscow, St. Petersburg & - & - & $\begin{array}{c}0.384 \\
(14.980) *\end{array}$ & $\begin{array}{c}0.352 \\
(14.370)^{*}\end{array}$ \\
\hline Region: North, North-West & - & - & $\begin{array}{c}0.200 \\
(6.130)^{*}\end{array}$ & $\begin{array}{c}0.229 \\
(7.370)^{*}\end{array}$ \\
\hline Region: Central & - & - & $\begin{array}{c}-0.115 \\
(-6.170)^{*}\end{array}$ & $\begin{array}{c}-0.107 \\
(-6.050)^{*}\end{array}$ \\
\hline Region: Volga & - & - & $\left(\begin{array}{c}-0.289 \\
-14.040)^{*}\end{array}\right.$ & $\begin{array}{c}-0.284 \\
(-14.500)^{*}\end{array}$ \\
\hline Region: Caucasus & - & - & $\begin{array}{c}-0.192 \\
(-7.010)^{*}\end{array}$ & $\begin{array}{c}-0.213 \\
(-8.190)^{*}\end{array}$ \\
\hline Region: Ural & - & - & $\left(\begin{array}{l}-0.024 \\
-1.110)\end{array}\right.$ & $\left(\begin{array}{c}-0.011 \\
-0.550)\end{array}\right.$ \\
\hline Region: West Siberia & - & - & $\begin{array}{c}0.302 \\
(10.210)^{*}\end{array}$ & $\begin{array}{c}0.283 \\
(10.070)^{*}\end{array}$ \\
\hline Region: East Siberia & - & - & $\begin{array}{c}0.093 \\
(3.020)^{*}\end{array}$ & $\begin{array}{c}0.108 \\
(3.670)^{*}\end{array}$ \\
\hline Std Dev: Region & - & - & 0.224 & 0.218 \\
\hline
\end{tabular}


Table 8: Continued...

\begin{tabular}{|c|c|c|c|c|}
\hline & $(1)$ & $(2)$ & $(3)$ & $(4)$ \\
\hline Employees: 1-9 & - & - & $\begin{array}{c}-0.263 \\
(-8.070)^{*}\end{array}$ & $\begin{array}{c}-0.192 \\
(-6.140)^{*}\end{array}$ \\
\hline Employees: $10-24$ & - & - & $\begin{array}{c}-0.150 \\
(-5.820)^{*}\end{array}$ & $\begin{array}{c}-0.101 \\
(-4.110)^{*}\end{array}$ \\
\hline Employees: 25-99 & - & - & $\begin{array}{c}-0.069 \\
(-4.250)^{*}\end{array}$ & $\begin{array}{c}-0.045 \\
(-2.890)^{*}\end{array}$ \\
\hline Employees: 100-249 & - & - & $\left(\begin{array}{l}0.027 \\
1.250)\end{array}\right.$ & $\left.\begin{array}{l}0.003 \\
0.130\end{array}\right)$ \\
\hline Employees: 250-999 & - & - & $\begin{array}{c}0.139 \\
(6.790)^{*}\end{array}$ & $\begin{array}{c}0.101 \\
(5.160)^{*}\end{array}$ \\
\hline Employees: GE 1000 & - & - & $\begin{array}{c}0.142 \\
(6.670)^{*}\end{array}$ & $\begin{array}{c}0.106 \\
(5.210)^{*}\end{array}$ \\
\hline Std Dev: Employees & - & - & 0.131 & 0.092 \\
\hline Gov't Owned Firm & - & - & $\begin{array}{c}-0.175 \\
(-7.500)^{*}\end{array}$ & $\begin{array}{c}-0.146 \\
(-6.510)^{*}\end{array}$ \\
\hline Education: LT Secondary & - & $\begin{array}{c}-0.229 \\
(-6.780)^{*}\end{array}$ & - & $\begin{array}{c}-0.182 \\
(-5.620)^{*}\end{array}$ \\
\hline Education: Secondary/Training & - & $\begin{array}{c}-0.053 \\
(-6.800)^{*}\end{array}$ & - & $\begin{array}{c}-0.047 \\
(-6.320)^{*}\end{array}$ \\
\hline Education: University & - & $\begin{array}{c}0.229 \\
(10.650)^{*}\end{array}$ & - & $\begin{array}{c}0.194 \\
(9.490)^{*}\end{array}$ \\
\hline Std Dev: Education & - & 0.137 & - & 0.115 \\
\hline Age & - & $\begin{array}{c}0.022 \\
(3.620)^{*}\end{array}$ & - & $\begin{array}{c}0.023 \\
(3.950)^{*}\end{array}$ \\
\hline $\operatorname{Age}^{2}$ & - & $\begin{array}{c}-0.000 \\
(-3.910)^{*}\end{array}$ & - & $\begin{array}{c}-0.000 \\
(-4.180)^{*}\end{array}$ \\
\hline Male & - & $\begin{array}{c}0.296 \\
(12.840)^{*}\end{array}$ & - & $\begin{array}{c}0.266 \\
(12.060) *\end{array}$ \\
\hline Married & - & $\begin{array}{l}0.034 \\
(1.480)\end{array}$ & - & $\begin{array}{c}0.047 \\
(2.180)^{*}\end{array}$ \\
\hline Constant & $\begin{array}{c}7.510 \\
(101.340)^{*}\end{array}$ & $\begin{array}{c}6.908 \\
(49.520)^{*}\end{array}$ & $\begin{array}{c}7.928 \\
(96.070)^{*}\end{array}$ & $\left(\begin{array}{c}7.222 \\
51.610)^{*}\end{array}\right.$ \\
\hline Year: 1994 & - & - & - & - \\
\hline Year: 1995 & $\begin{array}{c}-0.051 \\
(-2.020)^{*}\end{array}$ & $\begin{array}{c}-0.049 \\
(-2.060)^{*}\end{array}$ & $\begin{array}{c}-0.069 \\
(-2.860)^{*}\end{array}$ & $\begin{array}{c}-0.066 \\
(-2.900)^{*}\end{array}$ \\
\hline Year: 1996 & $\left(\begin{array}{l}-0.004 \\
(-0.140)\end{array}\right.$ & $\left(\begin{array}{l}-0.008 \\
(-0.290)\end{array}\right.$ & $\begin{array}{l}-0.026 \\
(-0.990)\end{array}$ & $\left(\begin{array}{l}-0.026 \\
(-1.030)\end{array}\right.$ \\
\hline Year: 1998 & $\begin{array}{c}-0.473 \\
(-16.770)^{*}\end{array}$ & $\left(\begin{array}{c}-0.479 \\
(-17.860)\end{array}\right.$ & $\begin{array}{c}-0.470 \\
(-17.560)^{*}\end{array}$ & $\left(\begin{array}{c}-0.473 \\
-18.540) *\end{array}\right.$ \\
\hline $\begin{array}{l}\text { Observations } \\
\mathrm{R}^{2}\end{array}$ & $\begin{array}{c}6725 \\
0.1235\end{array}$ & $\begin{array}{c}6725 \\
0.2199\end{array}$ & $\begin{array}{c}6725 \\
0.2174\end{array}$ & $\begin{array}{c}6725 \\
0.2983\end{array}$ \\
\hline
\end{tabular}


Table 9: RLMS: Wage Effects of Government Ownership

\begin{tabular}{lccc}
\hline & $($ Gov't $)$ & $($ Private $)$ & ( Difference $)$ \\
Ind: Manufacturing & -0.094 & 0.010 & -0.104 \\
& $(-4.070)^{*}$ & $(0.330)$ & $(-2.746)$ \\
Ind: Construction & 0.201 & -0.053 \\
& $(4.840)^{*}$ & $(4.580)^{*}$ & $(-0.769)$ \\
Ind: Transport, Communications & 0.224 & 0.262 & -0.037 \\
& $(7.360)^{*}$ & $(4.030)^{*}$ & $(-0.522)$ \\
Ind: Wholesale, Retail & 0.025 & 0.279 & -0.254 \\
& $(0.570)$ & $(7.300)^{*}$ & $(-4.725)^{a}$ \\
Ind: Housing, Utilities & 0.054 & 0.255 & -0.201 \\
& $(1.460)$ & $(2.580)^{*}$ & $(-1.909)$ \\
Ind: Health Services & -0.368 & -0.119 & $(-1.599)$ \\
Ind: Education, Sciences & $(-10.810)^{*}$ & $(-0.790)$ & -0.097 \\
Ind: Government & -0.405 & -0.309 & $(-0.861)$ \\
& $(-15.770)^{*}$ & $(-2.820)^{*}$ & -0.065 \\
Ind: Services & 0.098 & 0.163 & $(-0.514)$ \\
Ind: Mining, Oil, Gas & $(2.770)^{*}$ & $(1.350)$ & -0.365 \\
Ind: Finance, Insurance, Real Estate & -0.133 & 0.232 & $(-5.382)^{a}$ \\
Std Dev: Ind & $(-3.650)^{*}$ & $(4.100)^{*}$ & 0.109 \\
& $(4.640)^{*}$ & $(5.730)^{*}$ & $(0.890)^{a}$
\end{tabular}

IMPORTANT NOTE:

Eqn (Gov't) reports the total industry differential for "government owned" firms.

Eqn (Private) reports the total industry differential for NON- "government" or privately owned firms.

Eqn (Difference) reports the industry specific return to firm being "government owned".

Eqn (Difference)'s t-values concern whether the industry specific effect is significantly different

from the zero. The "a" marking however indicates the significance of the specific effect, compared to the overall effect, found in Table 8, Eqn (4), namely "Gov't Firm Owned" of $-14.6 \%$. 
Table 10: Wage Regressions: RLMS: By Year

\begin{tabular}{|c|c|c|c|c|}
\hline & $(94)$ & $(95)$ & $(96)$ & $(98)$ \\
\hline Ind: Manufacturing & $\begin{array}{c}-0.057 \\
(-1.860)^{*}\end{array}$ & $\begin{array}{c}-0.069 \\
(-2.050)^{*}\end{array}$ & $\begin{array}{c}-0.115 \\
(-2.730)^{*}\end{array}$ & $\begin{array}{l}-0.064 \\
(-1.350)\end{array}$ \\
\hline Ind: Construction & $\begin{array}{c}0.204 \\
(3.800)^{*}\end{array}$ & $\begin{array}{c}0.208 \\
(3.330)^{*}\end{array}$ & $\begin{array}{c}0.272 \\
(3.550)^{*}\end{array}$ & $\begin{array}{l}0.095 \\
(1.130)\end{array}$ \\
\hline Ind: Transport, Communications & $\begin{array}{c}0.191 \\
(4.030)^{*}\end{array}$ & $\begin{array}{c}0.165 \\
(3.240)^{*}\end{array}$ & $\begin{array}{c}0.366 \\
(5.650)^{*}\end{array}$ & $\begin{array}{c}0.292 \\
(4.580)^{*}\end{array}$ \\
\hline Ind: Wholesale, Retail & $\begin{array}{l}0.069 \\
(1.300)\end{array}$ & $\begin{array}{l}0.077 \\
(1.270)\end{array}$ & $\begin{array}{c}0.153 \\
(2.260)^{*}\end{array}$ & $\begin{array}{c}0.209 \\
(2.730)^{*}\end{array}$ \\
\hline Ind: Housing, Utilities & $\begin{array}{c}0.134 \\
(2.230)^{*}\end{array}$ & $\begin{array}{l}0.099 \\
(1.410)\end{array}$ & $\begin{array}{c}0.308 \\
(4.230)\end{array}$ & $\begin{array}{c}-0.173 \\
(-2.150)^{*}\end{array}$ \\
\hline Ind: Health Services & $\begin{array}{c}-0.256 \\
(-4.430)^{*}\end{array}$ & $\begin{array}{c}-0.280 \\
(-4.520)^{*}\end{array}$ & $\begin{array}{c}-0.403 \\
(-5.350)^{*}\end{array}$ & $\begin{array}{c}-0.386 \\
(-4.950)^{*}\end{array}$ \\
\hline Ind: Education, Sciences & $\begin{array}{c}-0.327 \\
(-7.550)^{*}\end{array}$ & $\begin{array}{c}-0.308 \\
(-6.690)^{*}\end{array}$ & $\begin{array}{c}-0.478 \\
(-8.060) *\end{array}$ & $\begin{array}{c}-0.404 \\
(-6.450) *\end{array}$ \\
\hline Ind: Government & $\begin{array}{c}0.114 \\
(1.940)^{*}\end{array}$ & $\begin{array}{c}0.145 \\
(2.270)^{*}\end{array}$ & $\begin{array}{l}0.098 \\
(1.340)\end{array}$ & $\begin{array}{c}0.149 \\
(1.680)^{*}\end{array}$ \\
\hline Ind: Services & $\begin{array}{l}-0.046 \\
(-0.890)\end{array}$ & $\begin{array}{l}0.013 \\
(0.220)\end{array}$ & $\begin{array}{l}-0.116 \\
(-1.540)\end{array}$ & $\begin{array}{l}-0.000 \\
(-0.000)\end{array}$ \\
\hline Ind: Mining, Oil, Gas & $\begin{array}{c}0.340 \\
(4.560)^{*}\end{array}$ & $\begin{array}{c}0.303 \\
(3.190)^{*}\end{array}$ & $\begin{array}{c}0.553 \\
(5.190)^{*}\end{array}$ & $\begin{array}{c}0.808 \\
(6.660)^{*}\end{array}$ \\
\hline Ind: Finance, Insurance, Real Estate & $\begin{array}{c}0.482 \\
(3.770)^{*}\end{array}$ & $\begin{array}{c}0.528 \\
(4.550)^{*}\end{array}$ & $\begin{array}{c}0.475 \\
(3.400)^{*}\end{array}$ & $\begin{array}{c}0.257 \\
(1.690)^{*}\end{array}$ \\
\hline Std Dev: Ind & 0.186 & 0.180 & 0.293 & 0.272 \\
\hline Occ: Legislators, Senior Managers, Officials & $\begin{array}{c}0.403 \\
(2.770)^{*}\end{array}$ & $\begin{array}{c}0.274 \\
(3.050)^{*}\end{array}$ & $\begin{array}{c}0.541 \\
(2.120)^{*}\end{array}$ & $\begin{array}{l}0.118 \\
(0.790)\end{array}$ \\
\hline Occ: Professionals & $\begin{array}{c}0.172 \\
(4.240)^{*}\end{array}$ & $\begin{array}{c}0.147 \\
(3.400)^{*}\end{array}$ & $\begin{array}{c}0.159 \\
(3.230)^{*}\end{array}$ & $\begin{array}{c}0.193 \\
(3.620)^{*}\end{array}$ \\
\hline Occ: Technicians, Professionals & $\begin{array}{l}0.042 \\
(1.070)\end{array}$ & $\begin{array}{c}0.073 \\
(1.840)^{*}\end{array}$ & $\begin{array}{c}0.097 \\
(2.040)^{*}\end{array}$ & $\begin{array}{l}0.078 \\
(1.550)\end{array}$ \\
\hline Occ: Clerks & $\begin{array}{c}-0.140 \\
(-2.440)^{*}\end{array}$ & $\begin{array}{c}-0.215 \\
(-3.530)^{*}\end{array}$ & $\begin{array}{c}-0.122 \\
(-1.690)\end{array}$ & $\begin{array}{c}-0.145 \\
(-1.860) *\end{array}$ \\
\hline Occ: Service, Market workers & $\begin{array}{l}-0.001 \\
(-0.020)\end{array}$ & $\begin{array}{c}-0.127 \\
(-2.080)^{*}\end{array}$ & $\begin{array}{c}-0.176 \\
(-2.240)^{*}\end{array}$ & $\begin{array}{l}-0.079 \\
(-0.940)\end{array}$ \\
\hline Occ: Craft and Related Trades & $\begin{array}{l}-0.019 \\
(-0.520)\end{array}$ & $\begin{array}{l}-0.005 \\
(-0.130)\end{array}$ & $\begin{array}{l}-0.035 \\
(-0.710)\end{array}$ & $\begin{array}{l}-0.069 \\
(-1.210)\end{array}$ \\
\hline Occ: Plant, Machine Operators, Assemblers & $\begin{array}{c}-0.074 \\
(-1.960)^{*}\end{array}$ & $\begin{array}{l}-0.011 \\
(-0.260)\end{array}$ & $\begin{array}{l}-0.045 \\
(-0.920)\end{array}$ & $\begin{array}{l}0.005 \\
0.090)\end{array}$ \\
\hline Occ: Elementary (unskilled) & $\begin{array}{c}-0.289 \\
(-5.430)^{*}\end{array}$ & $\begin{array}{c}-0.247 \\
(-4.430)^{*}\end{array}$ & $\begin{array}{c}-0.241 \\
(-3.520) *\end{array}$ & $\begin{array}{c}-0.361 \\
(-5.090) *\end{array}$ \\
\hline Std Dev: Occ & 0.124 & 0.117 & 0.123 & 0.136 \\
\hline Region: Moscow, St. Petersburg & $\begin{array}{c}0.247 \\
(6.040)^{*}\end{array}$ & $\begin{array}{c}0.334 \\
(7.260)^{*}\end{array}$ & $\begin{array}{c}0.440 \\
(8.420)^{*}\end{array}$ & $\begin{array}{c}0.452 \\
(7.070)^{*}\end{array}$ \\
\hline Region: North, North-West & $\begin{array}{c}0.324 \\
(5.980)^{*}\end{array}$ & $\begin{array}{c}0.291 \\
(5.260)^{*}\end{array}$ & $\begin{array}{c}0.156 \\
(2.270)^{*}\end{array}$ & $\begin{array}{l}0.054 \\
(0.710)\end{array}$ \\
\hline Region: Central & $\begin{array}{c}-0.170 \\
(-5.660)^{*}\end{array}$ & $\begin{array}{c}-0.083 \\
(-2.460)^{*}\end{array}$ & $\begin{array}{c}-0.092 \\
(-2.340)^{*}\end{array}$ & $\begin{array}{l}-0.061 \\
(-1.470)\end{array}$ \\
\hline Region: Volga & $\begin{array}{c}-0.266 \\
(-8.090)^{*}\end{array}$ & $\begin{array}{c}-0.329 \\
(-8.870)^{*}\end{array}$ & $\begin{array}{c}-0.294 \\
(-6.700) *\end{array}$ & $\begin{array}{c}-0.229 \\
(-4.960) *\end{array}$ \\
\hline Region: Caucasus & $\begin{array}{c}-0.269 \\
(-6.210)^{*}\end{array}$ & $\begin{array}{c}-0.304 \\
(-6.500)^{*}\end{array}$ & $\begin{array}{c}-0.097 \\
(-1.620)\end{array}$ & $\begin{array}{l}-0.086 \\
(-1.310)\end{array}$ \\
\hline Region: Ural & $\begin{array}{l}0.005 \\
0.150)\end{array}$ & $\begin{array}{l}0.029 \\
(0.800)\end{array}$ & $\begin{array}{l}0.012 \\
(0.260)\end{array}$ & $\begin{array}{c}-0.084 \\
(-1.750)^{*}\end{array}$ \\
\hline Region: West Siberia & $\begin{array}{c}0.355 \\
(7.380)^{*}\end{array}$ & $\begin{array}{c}0.386 \\
(7.550)^{*}\end{array}$ & $\begin{array}{c}0.239 \\
(3.890)^{*}\end{array}$ & $\begin{array}{l}0.076 \\
(1.080)\end{array}$ \\
\hline Region: East Siberia & $\begin{array}{c}0.246 \\
(5.170)^{*}\end{array}$ & $\begin{array}{l}0.051 \\
(0.930)\end{array}$ & $\begin{array}{l}-0.098 \\
(-1.330)\end{array}$ & $\begin{array}{l}0.093 \\
(1.330)\end{array}$ \\
\hline Std Dev: Region & 0.236 & 0.248 & 0.214 & 0.185 \\
\hline
\end{tabular}


Table 10: Continued...

\begin{tabular}{|c|c|c|c|c|}
\hline & $(94)$ & $(95)$ & $(96)$ & $(98)$ \\
\hline Employees: $1-9$ & $\begin{array}{c}-0.249 \\
(-4.980)^{*}\end{array}$ & $\begin{array}{c}-0.173 \\
(-2.820)^{*}\end{array}$ & $\begin{array}{l}-0.096 \\
(-1.370)\end{array}$ & $\begin{array}{c}-0.233 \\
(-2.920)^{*}\end{array}$ \\
\hline Employees: $10-24$ & $\begin{array}{c}-0.139 \\
(-3.230)^{*}\end{array}$ & $\begin{array}{c}-0.098 \\
(-2.270)^{*}\end{array}$ & $\begin{array}{c}-0.075 \\
(-1.310)\end{array}$ & $\begin{array}{l}-0.057 \\
(-0.960)\end{array}$ \\
\hline Employees: 25-99 & $\begin{array}{c}-0.053 \\
(-1.990) *\end{array}$ & $\begin{array}{l}-0.027 \\
(-0.920)\end{array}$ & $\begin{array}{l}-0.021 \\
(-0.610)\end{array}$ & $\begin{array}{c}-0.073 \\
(-1.990) *\end{array}$ \\
\hline Employees: 100-249 & $\begin{array}{l}0.031 \\
0.900)\end{array}$ & $\begin{array}{l}-0.012 \\
(-0.320)\end{array}$ & $\begin{array}{l}0.011 \\
0.240)\end{array}$ & $\left(\begin{array}{l}-0.042 \\
(-0.850)\end{array}\right.$ \\
\hline Employees: 250-999 & $\begin{array}{c}0.112 \\
(3.450)^{*}\end{array}$ & $\begin{array}{c}0.145 \\
(3.990)^{*}\end{array}$ & $\begin{array}{l}0.006 \\
(0.130)\end{array}$ & $\begin{array}{c}0.115 \\
(2.370)^{*}\end{array}$ \\
\hline Employees: GE 1000 & $\begin{array}{c}0.129 \\
(3.810)^{*}\end{array}$ & $\begin{array}{l}0.045 \\
(1.200)\end{array}$ & $\begin{array}{c}0.099 \\
(2.180)^{*}\end{array}$ & $\begin{array}{c}0.157 \\
(3.070)^{*}\end{array}$ \\
\hline Std Dev: Employees & 0.114 & 0.081 & 0.037 & 0.107 \\
\hline Gov't Owned Firm & $\begin{array}{c}-0.109 \\
(-2.920)^{*}\end{array}$ & $\begin{array}{c}-0.165 \\
(-3.870)^{*}\end{array}$ & $\begin{array}{c}-0.135 \\
(-2.680)^{*}\end{array}$ & $\begin{array}{c}-0.193 \\
(-3.540)^{*}\end{array}$ \\
\hline Education: LT Secondary & $\begin{array}{c}-0.223 \\
(-4.210)^{*}\end{array}$ & $\begin{array}{c}-0.167 \\
(-2.880)^{*}\end{array}$ & $\begin{array}{c}-0.197 \\
(-2.650)^{*}\end{array}$ & $\begin{array}{l}-0.137 \\
(-1.590)\end{array}$ \\
\hline Education: Secondary/Training & $\begin{array}{c}-0.046 \\
(-3.470)^{*}\end{array}$ & $\begin{array}{c}-0.028 \\
(-2.070)^{*}\end{array}$ & $\begin{array}{c}-0.035 \\
(-2.120)^{*}\end{array}$ & $\begin{array}{c}-0.075 \\
(-4.280) *\end{array}$ \\
\hline Education: University & $\begin{array}{c}0.206 \\
(5.520)^{*}\end{array}$ & $\begin{array}{c}0.137 \\
(3.640)^{*}\end{array}$ & $\begin{array}{c}0.167 \\
(3.710)^{*}\end{array}$ & $\begin{array}{c}0.257 \\
(5.500)^{*}\end{array}$ \\
\hline Std Dev: Education & 0.124 & 0.082 & 0.099 & 0.141 \\
\hline Age & $\begin{array}{l}0.010 \\
(0.970)\end{array}$ & $\begin{array}{c}0.039 \\
(3.730)^{*}\end{array}$ & $\begin{array}{l}-0.008 \\
(-0.600)\end{array}$ & $\begin{array}{c}0.052 \\
(3.700)^{*}\end{array}$ \\
\hline $\operatorname{Age}^{2}$ & $\begin{array}{l}-0.000 \\
(-1.020)\end{array}$ & $\begin{array}{c}-0.000 \\
(-3.600)^{*}\end{array}$ & $\begin{array}{l}0.000 \\
(0.290)\end{array}$ & $\begin{array}{c}-0.001 \\
(-3.840)^{*}\end{array}$ \\
\hline Male & $\begin{array}{c}0.308 \\
(8.040)^{*}\end{array}$ & $\begin{array}{c}0.247 \\
(6.060)^{*}\end{array}$ & $\begin{array}{c}0.221 \\
(4.470)^{*}\end{array}$ & $\begin{array}{c}0.280 \\
(5.380)^{*}\end{array}$ \\
\hline Married & $\begin{array}{l}0.050 \\
(1.330)\end{array}$ & $\begin{array}{c}0.068 \\
(1.700)^{*}\end{array}$ & $\begin{array}{l}0.069 \\
(1.420)\end{array}$ & $\begin{array}{l}-0.010 \\
(-0.210)\end{array}$ \\
\hline Constant & $\begin{array}{c}7.605 \\
(31.290) *\end{array}$ & $\begin{array}{c}6.734 \\
(26.780)^{*}\end{array}$ & $\left.\begin{array}{c}7.645 \\
(24.360)\end{array}\right)^{*}$ & $\begin{array}{c}6.094 \\
(17.870)^{*}\end{array}$ \\
\hline $\begin{array}{l}\text { Observations } \\
\mathrm{R}^{2}\end{array}$ & $\begin{array}{c}2186 \\
0.3006\end{array}$ & $\begin{array}{c}1842 \\
0.2873\end{array}$ & $\begin{array}{c}1396 \\
0.2753\end{array}$ & $\begin{array}{c}1301 \\
0.2720\end{array}$ \\
\hline
\end{tabular}


Table 11: Wage Regressions: RLMS Arrears Imputed: Pooled

\begin{tabular}{|c|c|c|c|c|}
\hline & $(1)$ & $(2)$ & $(3)$ & $(4)$ \\
\hline Ind: Manufacturing & $\begin{array}{l}-0.005 \\
(-0.410)\end{array}$ & $\begin{array}{l}-0.003 \\
(-0.310)\end{array}$ & $\begin{array}{c}-0.061 \\
(-5.440)^{*}\end{array}$ & $\begin{array}{c}-0.038 \\
(-3.710)^{*}\end{array}$ \\
\hline Ind: Construction & $\begin{array}{c}0.347 \\
(15.570)^{*}\end{array}$ & $\begin{array}{c}0.290 \\
(14.150)^{*}\end{array}$ & $\begin{array}{c}0.306 \\
(15.380)^{*}\end{array}$ & $\begin{array}{c}0.257 \\
(14.210)^{*}\end{array}$ \\
\hline Ind: Transport, Communications & $\left.\begin{array}{c}0.207 \\
(10.760)\end{array}\right)^{*}$ & $\begin{array}{c}0.205 \\
(11.430) *\end{array}$ & $\begin{array}{c}0.191 \\
(11.240)^{*}\end{array}$ & $\begin{array}{c}0.198 \\
(12.640)^{*}\end{array}$ \\
\hline Ind: Wholesale, Retail & $\begin{array}{c}-0.139 \\
(-7.210)^{*}\end{array}$ & $\begin{array}{l}0.004 \\
(0.200)\end{array}$ & $\begin{array}{c}-0.053 \\
(-2.810)^{*}\end{array}$ & $\begin{array}{c}0.053 \\
(2.880)^{*}\end{array}$ \\
\hline Ind: Housing, Utilities & $\begin{array}{c}0.213 \\
(8.610)^{*}\end{array}$ & $\begin{array}{c}0.234 \\
(10.390)^{*}\end{array}$ & $\begin{array}{c}0.179 \\
(8.180)^{*}\end{array}$ & $\begin{array}{c}0.190 \\
(9.680)^{*}\end{array}$ \\
\hline Ind: Health Services & $\begin{array}{c}-0.347 \\
(-15.310)^{*}\end{array}$ & $\left(\begin{array}{c}-0.361 \\
(-16.730\end{array}\right)^{*}$ & $\left(\begin{array}{c}-0.304 \\
(-14.960)^{*}\end{array}\right.$ & $\begin{array}{c}-0.315 \\
(-16.500)^{*}\end{array}$ \\
\hline Ind: Education, Sciences & $\left(\begin{array}{c}-0.355 \\
(-22.130)^{*}\end{array}\right.$ & $\left(\begin{array}{c}-0.418 \\
(-26.470)\end{array}\right.$ & $\left(\begin{array}{c}-0.284 \\
(-19.190)^{*}\end{array}\right.$ & $\left(\begin{array}{c}-0.360 \\
(-25.150) *\end{array}\right.$ \\
\hline Ind: Government & $\begin{array}{l}0.029 \\
(1.170)\end{array}$ & $\begin{array}{l}-0.008 \\
(-0.350)\end{array}$ & $\begin{array}{c}0.115 \\
(5.210)^{*}\end{array}$ & $\begin{array}{c}0.068 \\
(3.310)^{*}\end{array}$ \\
\hline Ind: Services & $\begin{array}{c}-0.117 \\
(-5.370)^{*}\end{array}$ & $\begin{array}{c}-0.096 \\
(-4.930)^{*}\end{array}$ & $\begin{array}{c}-0.068 \\
(-3.500)^{*}\end{array}$ & $\begin{array}{c}-0.063 \\
(-3.660)^{*}\end{array}$ \\
\hline Ind: Mining, Oil, Gas & $\begin{array}{c}0.637 \\
(18.980)^{*}\end{array}$ & $\left.\begin{array}{c}0.601 \\
(19.900)\end{array}\right)^{*}$ & $\begin{array}{c}0.407 \\
(13.360)^{*}\end{array}$ & $\begin{array}{c}0.390 \\
(14.440)^{*}\end{array}$ \\
\hline Ind: Finance, Insurance, Real Estate & $\begin{array}{c}0.319 \\
(6.070)^{*}\end{array}$ & $\begin{array}{c}0.319 \\
(6.730)^{*}\end{array}$ & $\begin{array}{c}0.366 \\
(7.890)^{*}\end{array}$ & $\begin{array}{c}0.361 \\
(8.730)^{*}\end{array}$ \\
\hline Std Dev: Ind & 0.251 & 0.252 & 0.203 & 0.211 \\
\hline Education: LT Secondary & - & $\begin{array}{c}-0.237 \\
(-11.650)^{*}\end{array}$ & - & $\begin{array}{c}-0.199 \\
(-11.190) *\end{array}$ \\
\hline Education: Secondary/Training & - & $\begin{array}{c}-0.035 \\
(-7.550)^{*}\end{array}$ & - & $\begin{array}{c}-0.029 \\
(-7.130)^{*}\end{array}$ \\
\hline Education: University & - & $\begin{array}{c}0.200 \\
(14.340)^{*}\end{array}$ & - & $\begin{array}{c}0.166 \\
(13.620) *\end{array}$ \\
\hline Std Dev: Education & - & 0.122 & - & 0.101 \\
\hline $\begin{array}{l}\text { Observations } \\
\mathrm{R}^{2}\end{array}$ & 8732 & 8732 & 8732 & 8732 \\
\hline
\end{tabular}

